\title{
Development of Electrode Materials for Li-Ion Batteries and Catalysts for Proton Exchange Membrane Fuel Cells
}

\author{
Hongkwan Yun¹, Dahee Kim¹, Chunjoong Kim¹, Young-Jin Kim², Ji Ho Min², Namgee Jung² \\ ${ }^{1}$ Chungnam National University, Dept. of Materials Science and Engineering, \\ ${ }^{2}$ Chungnam National University, Graduate School of Energy Science and Technology
}

\section{리튬 이차전지용 전극 및 연료전지 촉매 소재 연구 개발 동향}

\author{
윤홍관, 김다희', 김천중, ${ }^{\dagger}$, 김용진, 민지호', 정남기 ${ }^{2}$ \\ 1충남대학교 신소재공학과, ${ }^{2}$ 충남대학교 에너지기술과학대학원
}

(Received November 30, 2018; Accepted December 17, 2018)

\begin{abstract}
s
In this paper, we review about current development of electrode materials for Li-ion batteries and catalysts for fuel cells. We scrutinized various electrode materials for cathode and anode in Li-ion batteries, which include the materials currently being used in the industry and candidates with high energy density. While layered, spinel, olivine, and rock-salt type inorganic electrode materials were introduced as the cathode materials, the Li metal, graphite, Li-alloying metal, and oxide compound have been discussed for the application to the anode materials. In the development of fuel cell catalysts, the catalyst structures classified according to the catalyst composition and surface structure, such as Pt-based metal nanoparticles, non-Pt catalysts, and carbon-based materials, were discussed in detail. Moreover, various support materials used to maximize the active surface area of fuel cell catalysts were explained. New electrode materials and catalysts with both high electrochemical performance and stability can be developed based on the thorough understanding of earlier studied electrode materials and catalysts.
\end{abstract}

Keywords: Li-ion battery, Cathode, Anode, Fuel Cell, Catalyst

\section{1. 서론}

산업 발전 및 인구의 증가로 인해 에너지 수요가 급격 히 증가하면서 전 세계적으로 에너지원의 확보는 경제 및
산업 발달의 필수불가결한 핵심 요소가 되었다. 그러나 우리나라는 에너지 소비량 세계 10 위, 석유 소비량 6 위권 의 에너지 소비 국가임에도 불구하도, 약 $97 \%$ 의 에너지 수입 의존율을 가지고 있어 에너지 자립도가 매우 낮아 
심각한 에너지 수급 문제를 가지고 있으며, 에너지 안보 역시 매우 취약한 실정이다. 또한 이러한 에너지 수급 문 제와 함께 기후변화에 대한 이슈가 더해져 이를 타개하기 위한 새로운 국가전략 개발이 시급해지고 있다. 화석연료 의 사용으로 지구 온난화가 가속화되고 있으며 이대로 지 속되면 2100 년 대기 온도는 1900 년 대비 $2{ }^{\circ} \mathrm{C}$ 상승하게 되고, 해수면은 $50 \mathrm{~cm}$ 상승하는 등 심각한 기후 변화를 일으킬 것으로 예측된다. 이에 따라 1997년 교토 의정서 채택을 통해 선진국들을 중심으로 온실가스 중 가장 큰 영향을 미치는 이산화탄소의 배출량을 점진적으로 감소 시킬 것을 요구하였고, 2015년에는 프랑스 파리에서 열 린 제 21차 유엔 기후변화협약 당사국총회(COP21)에서 신기후체제 합의문인 파리 협정이 채택되면서 우리나라 를 포함한 모든 참여 국가가 이산화탄소 감축을 위한 기 후변화 대응에 동참해야 하는 의무를 갖게 되었다.

이러한 에너지 수급 및 기후변화 이슈를 동시에 해결하 기 위한 방법 중 하나로 이산화탄소를 배출하지 않는 친 환경 자동차 개발이 활발히 진행되고 있다. 가솔린, 디젤 등의 화석연료를 사용하고 있는 현재의 내연기관 자동차 배기가스에는 이산화탄소, 일산화탄소, 질소산화물 등 지구온난화 및 미세먼지의 원인이 되는 물질이 포함되어 있으며, 세계적으로 사용되고 있는 자동차 수의 증가로 인해 기후변화의 속도를 가속화시키는 주범이 되고 있다. 따라서 화석연료를 사용하지 않는 친환경 에너지 시스템 으로서 이차전지를 이용하는 전기 자동차 및 수소 연료전 지를 이용하는 연료전지 자동차 개발에 많은 관심이 모아 지고 있다.

최근 상용화되어 도로 위를 달리고 있는 전기 자동차에 서는, 전기화학적 산화/환원 반응이 가역적으로 일어날 수 있는 전극 소재들을 사용함으로써 반복적인 충방전이 가능하고 높은 에너지 밀도와 전압을 가지고 있는 리튬이 온전지를 동력원으로 사용하고 있다. 이러한 리튬이온전 지는 양극, 음극, 분리막 그리고 전해액으로 구성되는데, 양극과 음극은 반복적으로 리튬이온의 삽입(intercalation)과 탈리(deintercalation)가 가능한 안정한 구조로 이루어져 있어야 하며 전해질은 이온의 전달이 용이한 물 질이어야 하고, 분리막은 양극과 음극의 직접적인 접촉
을 막을 수 있어야 한다. 그러나 전기자동차에 사용되는 리튬이온전지는 고속 충전 시 매우 높은 열이 발생하게 되는데 이는 전지의 수명을 급격히 감소시킬 뿐 만 아니 라 폭발의 위험이 있어 안정적인 시스템 관리를 위해 약 2 시간 정도의 긴 시간 동안 느리게 충전해야한다는 단점 을 가지고 있고, 현재의 시스템으로는 1 회 충전 시 약 $300 \sim 400 \mathrm{~km}$ 정도의 주행가능 거리를 보여 주고 있어 고용량, 고출력의 이차전지 개발이 절실하다고 할 수 있 다. 특히, 이차전지를 구성하는 전극 소재는 전지의 용량 과 전압 즉 성능을 비롯해 출력, 수명 등 다양한 특성에 결정적인 역할을 하기 때문에 고용량, 고출력 리튬이온 전지를 개발하기 위해서는 전극 소재와 관련된 연구가 반 드시 필요하다.

이차전지를 이용하는 전기자동차 개발에 힘입어, 수소 를 연료로 사용 하는 수소연료전지 자동차 개발도 활발하 게 진행되고 있다. 수소연료전지는 전기화학적 수소 산화 및 산소 환원 반응을 통해 얻어지는 전기에너지를 사용하 는 에너지변환장치로서 최종적으로 이산화탄소 없이 물 만을 배출하는 친환경 발전시스템이다. 따라서 연료전지 자동차는 수소만 주입해주면 공기 중의 산소를 이용하여 무한한 전기에너지를 생산할 수 있으며, 이차전지를 사용 하는 전기자동차에 비해 수소 충전시간이 약 3 분 정도로 매우 빠르고, 1 회 수소 충전 시 주행가능 거리가 500 $600 \mathrm{~km}$ 정도로 매우 길다는 장점이 있다. 그러나 수소연 료전지 자동차에 사용되는 촉매 소재로 값비싼 백금 $(\mathrm{Pt})$ 을 사용하고 있어 경제성이 확보되지 못하고 있으며, 촉 매, 고분자 전해질 등 소재의 내구성이 확보되지 못하고 있어 상용화의 걸림돌이 되고 있다. 또한 이차전지를 이 용하는 전기자동차 충전소의 수가 빠르게 증가하고 있는 반면, 수소 충전 인프라 구축은 더디게 진행되고 있기 때 문에 많은 장점에도 불구하고 이차전지를 이용하는 전기 자동차와의 경쟁에서 뒤떨어지고 있다. 이러한 기술적 문 제점들을 보완하기 위한 고성능, 고내구성을 갖는 수소연 료전지 기술 개발이 요구되고 있으며, 특히 연료전지 시 스템을 구성하는 전극 소재 의 성능 및 내구성을 향상시 키는 획기적인 기술의 발전이 반드시 필요하다고 할 수 있다. 
따라서 본 고에서는 친환경 자동차로서 대두되고 있는 전기자동차 및 수소연료전지 자동차의 동력원으로 사용 되고 있는 리튬이온이차전지와 수소 연료전지를 구성하 고 있는 전극 소재의 기술개발 동향에 대해 소개 하고자 한다. 현재 산학연에서 활발히 연구가 진행중인 이차전지 용 전극 소재 및 연료전지용 촉매에 대하여 상세히 검토 하고, 이들 소재의 특성 및 요구조건에 대한 이해를 통해 더 높은 성능의 발현이 가능한 새로운 전극 및 촉매 소재 의 발굴이 가능할 것이다.

\section{2. 본론}

\section{1 리튬이차전지 양극 소재}

리튬 이차전지용 양극소재는 대표적으로 $\mathrm{LiMn}_{2} \mathrm{O}_{4}$ (LMO), $\mathrm{LiCoO}_{2}$ (LCO), $\mathrm{LiNi}_{\mathrm{x}} \mathrm{Co}_{\mathrm{y}} \mathrm{Mn}_{1-\mathrm{x}-\mathrm{y}} \mathrm{O}_{2}$ (NCM), $\mathrm{LiNi}_{0.8} \mathrm{Co}_{0.15} \mathrm{Al}_{0.05} \mathrm{O}_{2}(\mathrm{NCA}), \mathrm{LiFePO}_{4}(\mathrm{LFP})$ 등의 물질 들이 보고되었다. 이러한 양극 소재들의 결정구조는 크게 층상형, 스피넬구조, 올리빈 구조 등으로 분류되며, 구조 내 전이금속 산화물을 사용함으로써 평균 $3.6 \mathrm{~V}$ (vs. $\mathrm{Li}^{+} / \mathrm{Li}$ ) 정도의 전압을 얻을 수 있다. ${ }^{1-5)}$

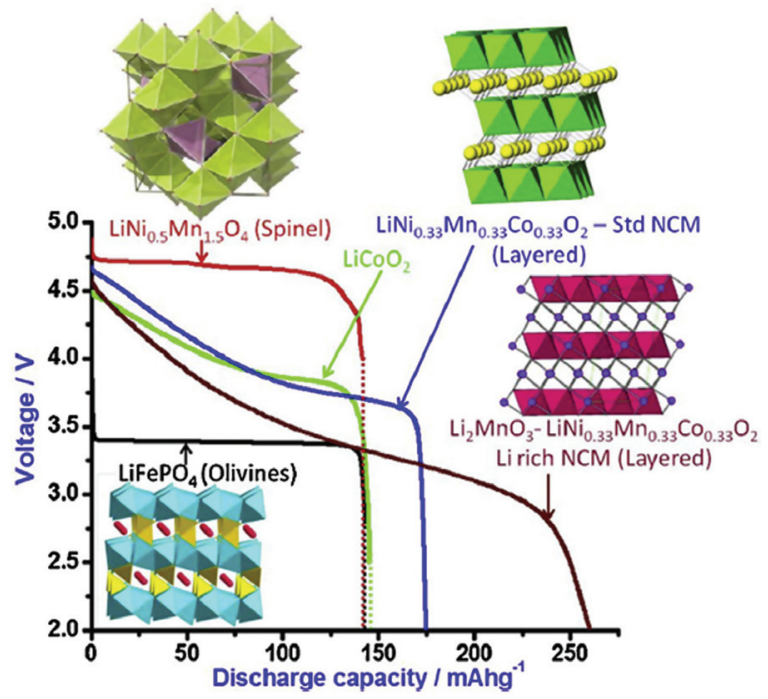

Fig. 1. Structures and voltage profiles of Li-ion battery cathode materials

\subsection{1 층상형 양극 소재}

기본적으로 양극소재는 높은 방전 전압과 높은 용량, 출력 그리고 수명을 필요로 한다. 층상구조의 대표적인 예로 리튬코발트산화물 $\left(\mathrm{LiCoO}_{2}\right)$ 을 들 수 있다. $\mathrm{LiCoO}_{2}$ 는 높은 작동 전압, 용량, 구조적 안정성, 리튬이온의 확 산 계수로 리튬 이차 전지의 양극소재 중에서도 가장 중 요한 소재로 사용되고 있다. 이러한 $\mathrm{LiCoO}_{2}$ 는 완전히 방 전된 상태에서 $\mathrm{Co}$ 가 +3 가로 존재하며, 이와 반대로 완전 히 충전된 상태의 경우에는 $\mathrm{Co}$ 가 +4 가로 존재하게 된다. 이러한 전이금속의 산화수 변화로 인해 리튬의 삽입/탈 리가 가능하다. 하지만, $\mathrm{LiCoO}_{2}$ 의 경우 $\mathrm{Li}$ 이 $50 \%$ 이상 탈리되면 $\mathrm{LiCoO}_{2}$ 의 층상구조는 유지되지 않는다. 전자 에너지관점에서 low spin $\mathrm{Co}^{3+}$ 에서 $3 \mathrm{~d}$ 전자의 energy level이 산소의 $2 \mathrm{p}$ orbital과 겹쳐 있어, $\mathrm{LiCoO}_{2} 1$ 몰 기준 리튬이 0.5 몰 이상 탈리되면 산소에서 전자가 함께 빠지 고 이로 인해 층상구조의 붕괴가 발생될 수 있으며, 이는 구조로부터의 가역적인 리튬의 삽입/탈리의 감소로 이어 진다. 가역적으로 삽입/탈리되는 리튬 이온의 양은 외부 도선으로 흐르는 전자의 양과 동일하므로, 가역적인 리튬 의 삽입/탈리 양의 감소는 양극 소재의 전지 용량 감소로 나타나게 된다. 따라서, $\mathrm{LiCoO}_{2}$ 를 안정적인 양극재로 사 용하기 위하여 리튬 이온 삽입/탈리 양을 $50 \%$ 이하로 제 한하여 왔으며, 이에 따른 용량은 약 $140 \mathrm{mAh} / \mathrm{g}$ 에 해당 된다.

또 다른 층상 구조의 대표적인 예로 리튬니켈산화물 $\left(\mathrm{LiNiO}_{2}\right)$ 가 있다. 동일한 층상 구조를 가지는 전이금속 산화물인 $\mathrm{LiNiO}_{2}$ 은 $\mathrm{Co}$ 대비 값이 싸고 독성이 적은 $\mathrm{Ni}$ 을 사용한다. $\mathrm{LiNiO}_{2}$ 에서는 $\mathrm{Ni}$ 이 $\mathrm{Ni}^{3+}$ 로 존재해야 하지만, low spin 니켈 이온이 팔면체 자리에서 쌍을 이루지 못한 스핀이 발생하여 불안정하기 때문에, 상대적으로 안정한 $\mathrm{Ni}^{2+}$ 가 형성된다. 이 때 $\mathrm{Ni}^{2+}(\mathrm{r}=0.69 \AA)$ 는 $\mathrm{Li}^{+}(\mathrm{r}=0.76 \AA)$ 과 유사한 이온 반경을 가지게 되며, $\mathrm{Ni}^{2+}$ 가 리튬 층에 치 환된 고용체를 형성하여 원하는 화학 조성 당량을 갖는 $\mathrm{LiNiO}_{2}$ 를 합성하기 어렵고, 실제적으로 비양론적 조성인 $\mathrm{Li}_{1-\mathrm{x}} \mathrm{Ni}_{1+\mathrm{x}} \mathrm{O}_{2}$ 가 합성된다. 이에 따라 $\mathrm{NiO}_{2}$ 층들이 국부적 인 3 차원 구조를 형성하여 리튬 이온의 확산을 방해하여 특성이 저하될 뿐만 아니라, 충 - 방전 과정에서의 비가역 

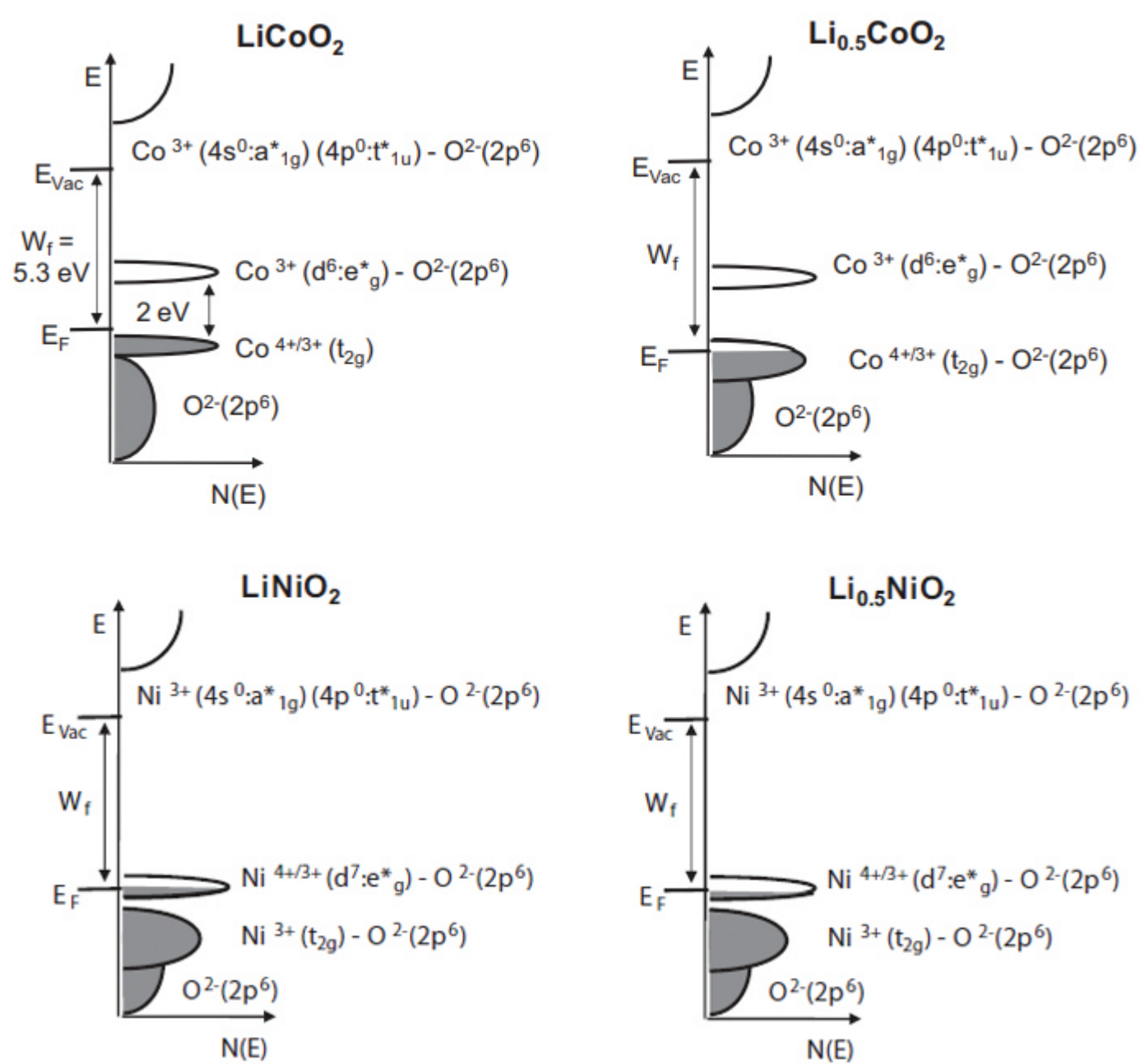

Fig. 2. The electronic band structure of $\mathrm{LiCoO}_{2}, \mathrm{Li}_{0.5} \mathrm{CoO}_{2}, \mathrm{LiNiO}_{2}$ and $\mathrm{Li}_{0.5} \mathrm{NiO}_{2}{ }^{8)}$

상전이로 인하여 용량이 저하된다는 단점이 있다. 리튬 망간산화물 층상구조형 소재 $\left(\mathrm{LiMnO}_{2}\right)$ 의 경우, $\mathrm{LiMnO}_{2}$ 1 몰 대비 리튬 이온이 0.5 몰 이상 구조에서 탈리될 시 $\mathrm{Li}_{0.5} \mathrm{MnO}_{2}$ 조성에서 리튬 이온의 팔면체 자리에서 사면체 자리로의 이동이 발생하여 층상구조에서 스피넬 구조로 상전이가 일어나게 된다. 위의 단점으로 인하여 $\mathrm{LiNiO}_{2}$ 와 $\mathrm{LiMnO}_{2}$ 는 리튬 이차 전지 양극으로 활용되지 못하고 있다. ${ }^{7)}$

단일 전이금속산화물의 전기화학적 특성을 향상시키 기 위해 전이금속의 조합에 대해여 연구가 진행되고 있 다. 특히, 리튬니켈코발트망간산화물 $\left(\mathrm{LiNi}_{\mathrm{x}} \mathrm{Co}_{\mathrm{y}} \mathrm{Mn}_{1-\mathrm{x}-}\right.$ ${ }_{\mathrm{y}} \mathrm{O}_{2}, \mathrm{NCM}$ )은 3 개의전이금속 $\mathrm{Ni}, \mathrm{Co}, \mathrm{Mn}$ 으로 이루어진
3성분계 층상구조 양극소재이다. $\mathrm{NCM}$ 소재는 $\mathrm{LiCoO}_{2}$ 의 높은 출력 특성과 $\mathrm{LiNiO}_{2}$ 의 고용량성, $\mathrm{LiMnO}_{2}$ 에서 망간 의 열적 안정성 및 낮은 가격의 장점을 가질 수 있다. 특 히, 전이금속 비율이 동일하게 혼합된 $\mathrm{LiNi}_{1 / 3} \mathrm{Co}_{1 / 3} \mathrm{Mn}_{1 / 3} \mathrm{O}_{2}$ 에서는 $\mathrm{Ni}, \mathrm{Co}, \mathrm{Mn}$ 이 각각 $\mathrm{Ni}^{2+}, \mathrm{Co}^{3+}, \mathrm{Mn}^{4+}$ 로 구성된 다. 충전의 경우 리튬은 탈리반응이 진행되고, $\mathrm{Ni}^{2+}$ 의 산 화수가 먼저 증가하게 된다. $\mathrm{Co}^{3+}$ 는 고전압 영역에서 활 성화되고, $\mathrm{Mn}^{4+}$ 의 경우는 전기화학 반응을 하지 않는다. 리튬의 삽입반응 시에는 이러한 반응이 역방향으로 진행 되고, 따라서 $\mathrm{Co}$ 와 $\mathrm{Ni}$ 의 환원반응이 진행된다. $\mathrm{NCM} 111$ 은 충전 시 리튬이 $60 \%$ 이상 탈리되어도 구조변화가 거 의 없는 안정한 구조를 이루고 있기에 수명 특성이 우수 
하다는 장점이 있다. 이러한 NCM111의 장점은 유지하고 용량을 향상시키기 위해 $\mathrm{Ni}$ 의 함량을 높인 양극 소재를 $\mathrm{Ni}-$ rich $\mathrm{NCM}$ 이라 한다. $\mathrm{Ni}$ 의 함량이 높을수록 $\mathrm{Ni}$ 의 평 균산화가수는 증가하게 된다. 이때, $\mathrm{Ni}, \mathrm{Co}, \mathrm{Mn}$ 의 산화/ 환원 경향에 따라, $\mathrm{Co}$ 와 $\mathrm{Mn}$ 은 항상 +3 과 +4 의 산화가 수를 유지한다. $\mathrm{NCM}$ 소재에서 $\mathrm{Ni}$ 의 함량이 높을수록 용 량이 커지는 이유는 $\mathrm{Co}^{3+}$ 와 $\mathrm{Ni}^{3+}$ 이온들이 팔면체자리에 위치할 때, 전이금속 d 궤도함수의 에너지 준위 때문이 다. $\mathrm{Co}^{3+}$ 는 $\mathrm{d}$ 오비탈의 전자 6 개가 모두 $\mathrm{t}_{2 \mathrm{~g}}$ 에 있는 저스 핀 상태이고 $\mathrm{Ni}^{3+}$ 는 $\mathrm{d}$ 오비탈의 전자 7 개가 $\mathrm{t}_{2 \mathrm{~g}}$ 에 6 개, $\mathrm{e}_{\mathrm{g}}$ 에 1 개 위치하므로 $\mathrm{Ni}^{3+}$ 의 전자의 에너지가 더 높아 전자 가 쉽게 방출될 수 있으므로, 리튬 대비 낮은 전압에서 더 많은 리튬이온을 이동시킬 수 있다.

\subsection{2스피넬계 양극소재}

스피넬 구조는 $\mathrm{AB}_{2} \mathrm{O}_{4}$ 의 조성을 갖는 결정구조의 하나 로서 대표적으로 $\mathrm{LiMn}_{2} \mathrm{O}_{4}$ 가 있다. 이러한 스피넬 구조는 층상형 구조와 달리 구조의 변형 없이 $4 \mathrm{~V}$ 대역에서 리튬 이온의 삽입/탈리가 가능하다. 특히 $\mathrm{Mn}$ 은 가격이 저렴 하고, 독성이 없기 때문에 많은 주목을 받고 있다. 또한, 입체적 구조로써 리튬이 탈리되어도 구조의 유지가 가능 하며, 리튬 이온의 확산도 빠르다. 하지만 $\mathrm{LiMn}_{2} \mathrm{O}_{4}$ 의 경 우, $\mathrm{Mn}^{3+}$ 은 화학적으로 불안정하기 때문에, $\mathrm{Mn}^{2+}$ 와 $\mathrm{Mn}^{4+}$ 상태로 나뉘게 된다. 이것은 가역반응물은 $\mathrm{Mn}^{3+}$ 의 감소를 야기하고, $\mathrm{Mn}^{2+}$ 의 전해액으로의 용출을 야기한 다. 고온에서는 이러한 반응들이 더욱 가속화되기 때문에 안정성 확보가 필요하다. 이러한 열화는 이종원소로 도핑 을 하거나, 작동 전압대를 높여 $\mathrm{Li}_{x} \mathrm{Mn}_{2} \mathrm{O}_{4}$ 의 조성에서 소 재가 구동될 수 있도록 제어하여 전지의 열화 현상을 해 결하고 있다. 이러한 해결 방안들은 궁극적으로 소재의 가역적인 전지용량을 제한하기 때문에 최근에는 표면을 안정화하는 연구가 적극적으로 진행되고 있다. 또한, 스 피넬 구조에서 망간을 타 전이금속으로 치환하게 될 때, 치환된 전이 금속의 산화환원 전위에 따라 전압의 제어가 가능하다. 특히, $\mathrm{LiNi}_{0.5} \mathrm{Mn}_{1.5} \mathrm{O}_{4}$ 의 경우에 모든 $\mathrm{Mn}$ 은 $4+$ 상태로 존재하게 된다. 따라서, $\mathrm{Ni}^{2+}$ 에서 $\mathrm{Ni}^{4+}$ 로의 산화/ 환원 반응만을 통하여 리튬의 삽입/탈리 반응이 일어나
기 때문에, $\mathrm{Mn}^{4+/ 3+}$ 대비 전압이 약 $4.8 \mathrm{~V}$ 로 매우 높으며, 용량 저하가 적다고 알려져 있다.

\subsection{3올리빈계 양극소재}

올리빈 구조를 가지는 양극 소재의 대표적인 예로 리튬 철인산화물 $\left(\mathrm{LiFePO}_{4}, \mathrm{LFP}\right)$ 이 있다. 이 소재의 가장 큰 장점은 전이금속으로 철을 사용하는 것이다. 일반적인 리 튬 이차 전지 양극소재에 사용되는 고가, 독성의 코발트 대신에 저렴하고 무독성인 철을 사용하여 소재의 가격적 측면과 친환경적인 이점이 있다. 올리빈 구조의 경우 강 한 P-O 결합으로 인하여 구조적으로 안정성을 갖는다. 이 때문에 과충전에 안정하며 고압, 고온에서도 사용이 가능하다. 하지만, 리튬 확산 채널이 1-dimensional (1$\mathrm{D}$ ) 이기에, 2-D(층상) 혹은 3-D(스피넬)인 타 소재 대 비 리튬 이온의 확산속도가 느려 출력이 낮은 문제가 있 다. 이러한 이유로 마이크로미터 수준에서는 전지특성이 거의 발현되지 않고 수십 나노미터 이하 크기에서만 그 전지 특성이 발현된다.

$\mathrm{LiFePO}_{4}$ 양극 소재는 이론 용량 $170 \mathrm{mAh} / \mathrm{g}$, 실제 용 량 $160 \mathrm{mAh} / \mathrm{g}$ 으로 가용 용량이 실제 용량에 근접했음을 알 수 있으나, 이론 용량 자체가 일반적으로 많이 쓰이는 $\mathrm{LiNi}_{\mathrm{x}} \mathrm{Co}_{\mathrm{y}} \mathrm{Mn}_{1-\mathrm{x}-\mathrm{y}} \mathrm{O}_{2}$ 양극 소재(이론 용량 $278 \mathrm{mAh} / \mathrm{g}$ ) 에 비해 많이 부족하다. 또한, 방전 전압 $\left(3.4 \mathrm{~V} \mathrm{VS.} \mathrm{Li}^{+} / \mathrm{Li}\right)$ 이 $4 \mathrm{~V}$ 급인 층상 구조형 혹은 스피넬 구조형 대비 낮다. 하지만, 올리빈 구조의 구조 안정성, 열적 안정성, $\mathrm{Fe}$ 또 는 $\mathrm{Mn}$ 을 사용함에 따라 친환경성, 가격경쟁력을 가지기 에 차세대 배터리산업을 이끌 것이라는 전망이 있다. 특 히, 구조 내에서 $\mathrm{Mn}$ 을 가지는 올리빈 구조의 경우 평균 방전 전압이 $4 \mathrm{~V}$ 로 높아 많은 주목을 받고 있다.

\subsection{4 과잉리튬의 양극소재}

리튬 이차 전지의 용량을 증가시키기 위하여, 양극소재 에 리튬의 양을 늘리려는 많은 연구가 진행되고 있다. Fig. 3 과 같이 기존의 양극 소재와 비교하여, 더 적은 양 의 전이 금속을 통하여 $\mathrm{Li}_{2} \mathrm{MeO}_{3}$ 혹은 $\mathrm{Li}_{3} \mathrm{MeO}_{4}$ 와 같이 리 튬 함량을 늘릴 수 있다. 이것은 암염 구조를 가지며, 대 표적으로 $\quad \mathrm{Li}_{3} \mathrm{NbO}_{4}$ 가 있다. $\quad \mathrm{Li}^{+}(\mathrm{r}=0.76 \AA)$ 과 


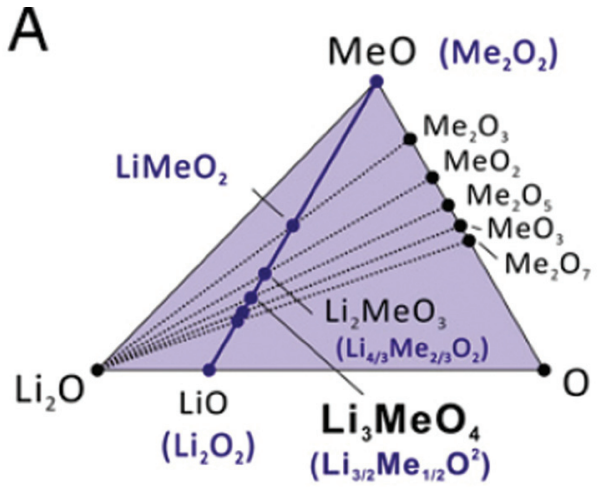

Fig. 3. An expanded view of a $\mathrm{Li}-\mathrm{Me}-\mathrm{O}$ triangular phase diagram $^{10)}$

$\mathrm{Nb}^{5+}(\mathrm{r}=0.65 \AA)$ 는 비슷한 이온 반경을 통해서 서로가 치 환가능하다. 따라서, 더 많은 $\mathrm{Li}$ 을 함유할 수 있으며, 다 양한 전이 금속을 첨가함으로써 암염구조를 유지하면서 리튬의 삽입/탈리가 가능하게 한다. 그러나, $\mathrm{Li}$ 의 확산을 증가시키는데 필요한 과량의 $\mathrm{Li}$ 는 전이 금속의 산화/환 원 센터를 감소시켜 용량 감소를 야기한다. 따라서, 전기 화학적 특성을 최대화하기 위해 조성의 적절한 조절이 필 요하다. 현재는 50도에서 250-300 mAh/g의 용량이 구
현되고 있으며, 기존의 층상구조 기반 전이금속산화물 양 극소재의 재료적 한계를 넘어 새로운 양극소재의 방향을 제시하고 있다. ${ }^{9-10)}$

\section{2 음극소재}

리튬 이차 전지의 음극 소재로써 1990년대부터 상용화 되어 있는 흑연, 흑연 외에 다양한 탄소계 소재, 리튬과 합금화가 가능한 $\mathrm{Si}, \mathrm{Sn}$ 등 금속 소재, $\mathrm{Ti}$ 계 산화물 소재 등이 알려져 있다. 그 외에도 궁극적인 리튬 이차 전지의 음극이라고 하는 리튬 금속 또한 꾸준한 연구가 진행되고 있다. 음극과 양극의 전위 차이가 전지 전압으로 나타나 는 것이므로 음극 소재에서 전위가 낮아야 상대적으로 높 은 전위를 갖는 양극과 결합하여 전지로 제작되었을 때, 높은 전압을 얻을 수 있다. 전지전압이 낮으면 같은 용량 이라 하더라도 저장할 수 있는 전력량이 작아지므로 에너 지밀도 측면에서는 불리하기 때문에, 음극 소재의 전위는 상대적으로 낮아야 한다. ${ }^{11}$

\subsection{1 리튬금속}

리튬 이차전지의 음극소재에 대한 연구는 리튬금속으

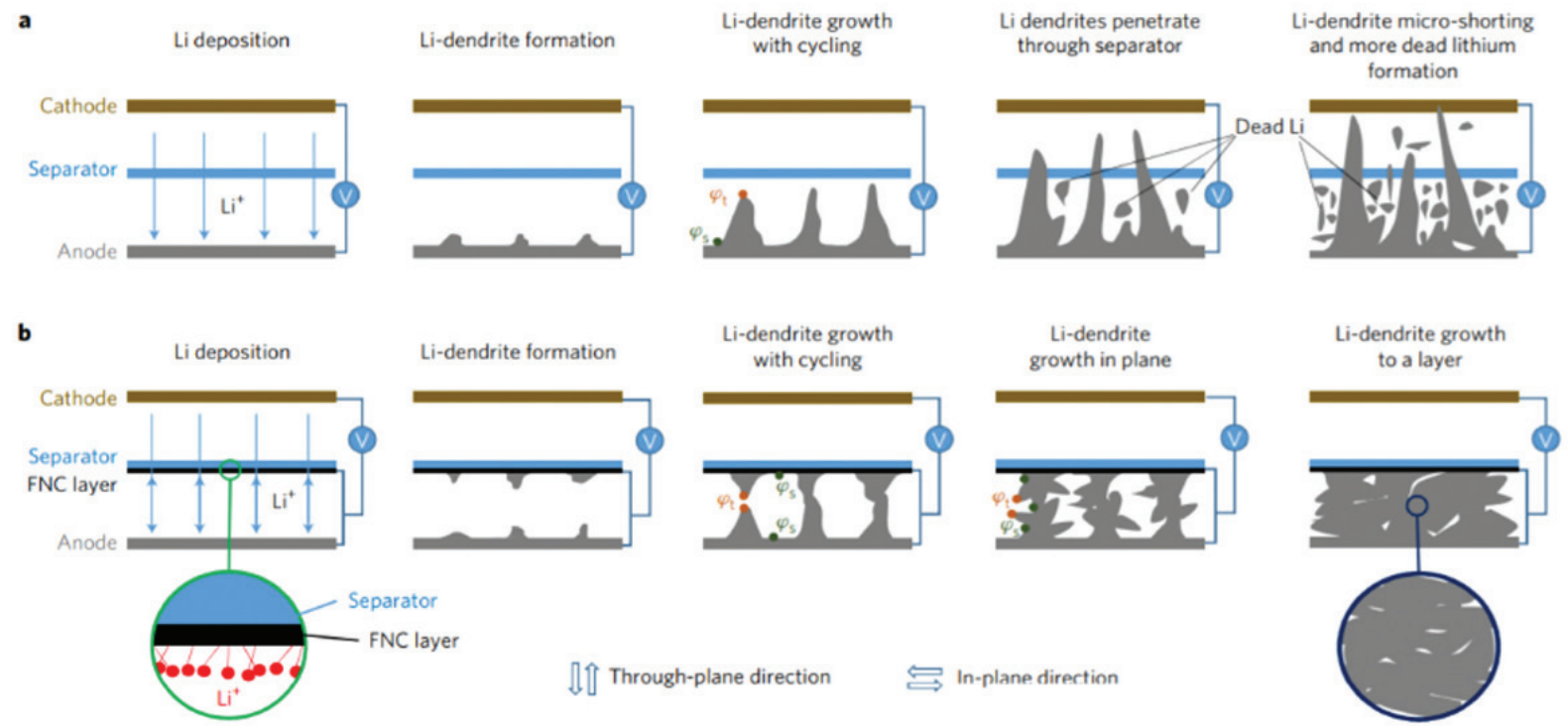

Fig. 4. Dendrite growth in Li-ion battery with clean separator and functionalized nanocarbon-coated separator ${ }^{12)}$ 


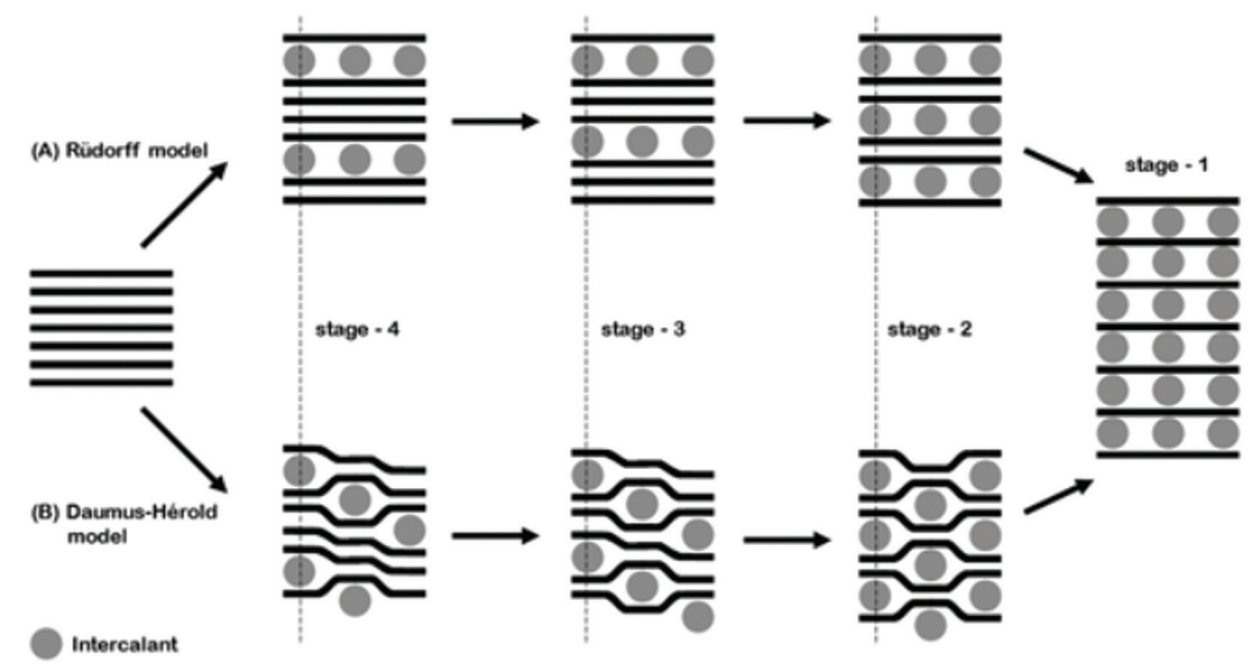

Fig. 5. (A) Rudorff and (B) Daumas - Herold models of ion intercalation into graphite ${ }^{14)}$

로 시작되었다. 리튬 금속은 높은 용량과 작동 전압을 구 현할 수 있다. 그러므로 높은 단위 용량과 가장 낮은 전 위를 통하여 리튬 이차 전지의 궁극적인 음극소재로 평가 받고 있다. 하지만, 리튬 금속은 수용액 전해질에서 큰 반 응성을 가지기 때문에 음극으로 사용하지 못하였지만 비 수용성 유기 전해질에서의 활용가능성을 찾아 연구가 진 행되었다. 리튬금속은 그 외에도, 충방전 동안에 리튬 금 속의 전해액으로의 용출과 리튬으로의 재석출을 반복하 면서 특정부분으로 성장하는 수지상(dendrite)이 형성된 다. 이러한 수지상 성장을 통해서 내부 단락 등 안정성에 문제가 발생할 수 있고, 이로 인해 리튬 금속은 상용화되 지 못하였다. 하지만, 높은 에너지 밀도를 요구하는 전지 성능에 부합하기 위하여 리튬 금속의 표면 개선 및 새로 운 층을 이용하여 문제되었던 수지상 형성을 억제하는 연 구가 진행되고 있다.

\subsection{2 탄소계 소재}

리튬 표면의 수지상의 성장 문제로 리튬의 삽입이 가능 한 탄소계 재료가 사용하게 되었다. 현재 상용화된 리튬 이차 전지는 흑연 기반의 음극을 사용한다. 이러한 탄소 계 소재들은 리튬을 포함하고 있지 않지만, 리튬 원자가 존재할 수 있는 공간을 부여하기 때문에, 외부도선으로
전자가 이동하고 전해액을 통해 리튬 이온이 이동함으로 써 충/방전이 가능하다. 흑연은 리튬대비 낮은 전압 $\left(\sim 0.25 \mathrm{~V} \mathrm{VS.} \mathrm{Li}^{+} / \mathrm{Li}\right)$ 을 가지며, 매우 안정적이기 때문 에 다른 음극재에 비하여 월등한 수명 특성을 보여준다. 하지만, 재료 자체의 낮은 이론 용량 $(372 \mathrm{mAh} / \mathrm{g})$ 으로 인해 고용량 배터리의 적용에 한계가 있다 ${ }^{13)}$. 흑연에서 의 리튬 삽입 반응은 흑연의 모서리면을 통하여 일어난 다. $\sim 0.25 \mathrm{~V}\left(\mathrm{vs} . \mathrm{Li}^{+} / \mathrm{Li}\right)$ 이하의 전위에서 발생하는 리 튬의 삽입 반응의 경우, 리튬은 인접한 흑연층에 삽입 되 지 않는다. 하지만, 리튬의 양이 점점 증가하게 되면서 최 종적으로 모든 흑연층에 리튬이 채워지게 되면서 리튬과 흑연이 교대로 배열되게 된다. 이렇듯 충전 시에 리튬이 삽입되는 단계를 스테이징이라고 한다. 충전이 진행되면 서 낮은 스테이지로 변화하며 방전 시에는 반대로 진행하 게 된다. 이러한 구조적인 변화를 통하여 흑연은 372 $\mathrm{mAh} / \mathrm{g}$ 의 용량을 구현할 수 있다.

\subsection{3 실리콘}

리튬과의 합금/탈합금 반응을 통한 음극으로 $\mathrm{Si}, \mathrm{Al}$, $\mathrm{Sn}, \mathrm{Ge}$ 등이 있다. 이 재료는 기존의 탄소계 음극에 비해 무게당, 부피당 용량에서 상당히 우수하다. 따라서 고용 량 리튬 이차 전지 재료로서 많은 연구가 진행되고 있다. 
a

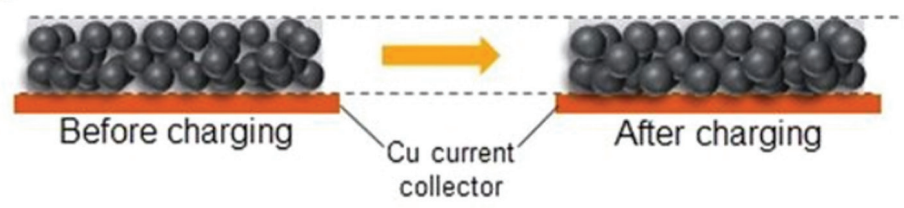

b

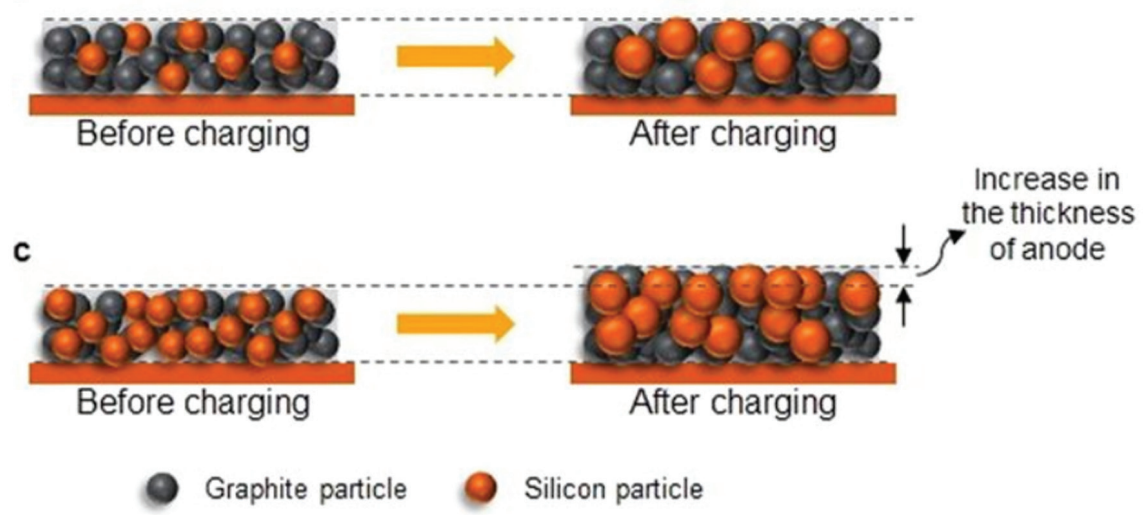

Fig. 6 . The schematic showing cross-section of anode before and after charging ${ }^{17}$

이 중에서 특히 실리콘의 경우 음극재 중 가장 높은 이론 용량( 4200 mAh/g)을 갖는다. 또한, 낮은 전위와 친환 경적이고 매장량이 많은 장점이 있다. 이러한 실리콘의 가장 큰 문제점은 부피 팽창이다. 리튬과의 반응 중에 $300 \%$ 에 달하는 부피 팽창이 일어나는데 흑연이 경우 $10 \%$ 부피변화를 고려하면 이는 상당한 수치이다. 충/방 전 시에 부피변화는 기계적 열화 및 임피던스의 향상을 야기할 수 있다. 따라서 이를 해결하기 위하여 탄소-실 리콘 복합체를 통한 부피팽창의 최적화에 많은 연구가 진

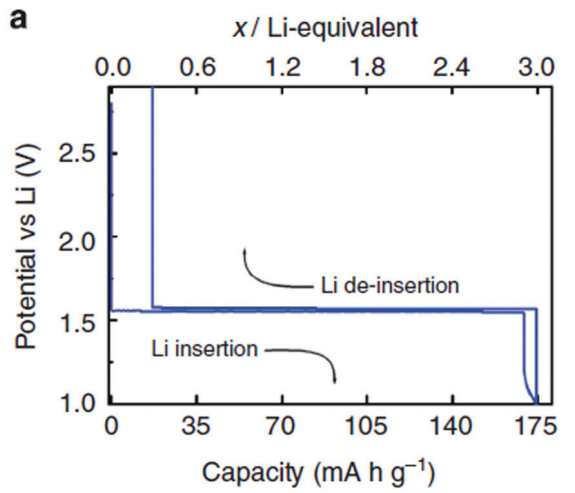

Fig. 7. Electrochemical properties of the LTO electrode ${ }^{20)}$
행되고 있다. ${ }^{15-16)}$

\subsubsection{Ti 계열 산화물}

삽입/탈리 반응으로 충방전이 발생하는 대표적인 음극 으로 $\mathrm{Li}_{4} \mathrm{Ti}_{5} \mathrm{O}_{12}$ (LTO)가 있다. $\mathrm{LTO}$ 는 낮은 용량과 전압 에도 불구하고 높은 열적 안정성, 사이클 수명 등 여러 장 점들을 가진다. 그 중에서도 가장 큰 장점은 체적 변화가 적다는 것인데, 리튬이온이 삽입/탈리될 때 일어나는 상 변화가 매우 미세한 체적 변화를 유발하기 때문이다. 이

b

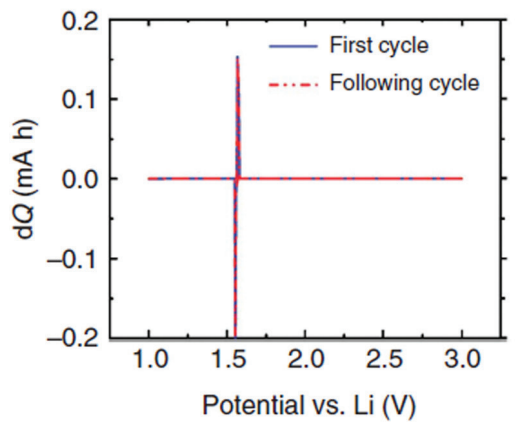


특 집 ㅁㅁ윤홍관, 김다희, 김천중, 김용진, 민지호, 정남기

러한 상변화 덕분에 LTO는 현재의 보고된 음극소재 중 안정성이 가장 탁월하다. 또한, 높은 평형 전위값

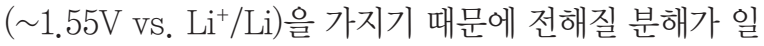
어나지 않아 고체-전해질 간 계면(Solid Electrolyte Interface, SEI)을 형성하지 않고, Li의 수지상 형성을 방지하여 안전하다. 뿐만 아니라, 출력 특성이 좋기 때문 에 급속 충 · 방전용 전지에 많이 사용되고 있다. LTO 음 극 소재는 3 차원의 리튬 이온 환산경로를 가지기에, 낮은 전기전도성 $\left(\sim 10^{-13} \mathrm{~S} / \mathrm{cm}\right)$ 를 나노 크기화를 통하여 극 복한다면 급속 충방전이 가능하다. 하지만, LTO 의 경우 나노크기로 합성시, 하소과정에서 아나타제 구조의 형성 으로 인해 비가역 용량이 증가하는 문제가 있다. ${ }^{18-19)}$

\section{3 수소 연료전지 전극 소재}

수소 연료전지 시스템에서 직접적으로 전기를 생산하 는 막전극접합체(membrane electrode assembly, $\mathrm{MEA}$ )는 고분자 전해질막(polymer electrolyte membrane) 양면에 애노드(수소 산화 전극) 및 캐소드(산

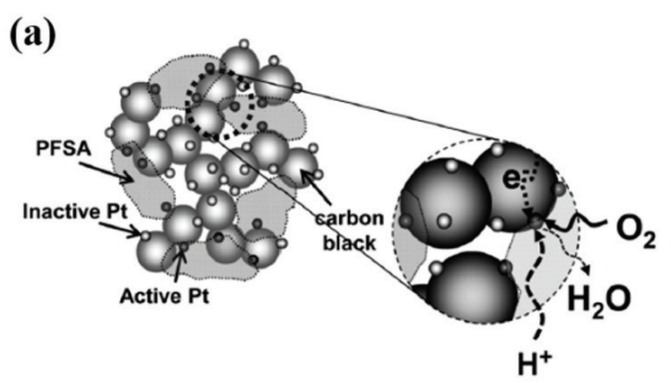

(b)

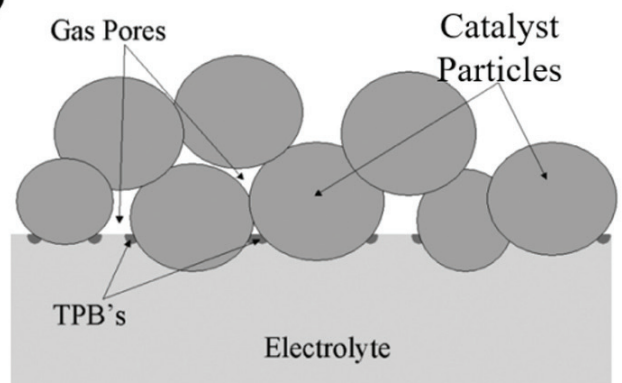

Fig. 8. Schematic illustrations of (a) the structure of catalyst-ionomer agglomerates in electrode ${ }^{21)}$ and (b) the triple phase boundaries (TPBs). ${ }^{22)}$
소 환원 전극)가 접합되어 있는 구조를 가지며, 일반적으 로 각 전극 내부는 탄소 담지체 표면에 고분산된 촉매 나 노 입자와 수소 이온를 전달하기 위한 이오노머의 응집체 로 구성된 다공성 구조로 제작된다. ${ }^{21)}$ 이러한 전극 구조 내에서, 외부로부터 주입된 수소 또는 산소 기체가 촉매/ 이오노머 경계면을 만나게 되면 전기화학 반응이 일어나 게 되는데, 반응 기체-촉매 표면-이오노머의 3 가지 상 (phase)이 접하는 부분을 삼상계면(triple phase boundary, TPB)이라고 부르며, ${ }^{22)}$ 연료전지 성능 향상을 위해 삼상계면의 수를 극대화하기 위한 노력을 하고 있다.

이러한 삼상계면을 구성하는 요소 중 촉매 나노 입자는 수소 산화 또는 산소 환원 반응을 위한 전기화학적 활성 을 띠어야 하고, 촉매 효율을 높이기 위해 넓은 활성 표면 을 가져야 하며, 전자를 빠르게 전달하기 위한 전기전도 도를 가져야만 한다. 또한, 연료전지 촉매는 장시간 운전 안정성을 확보하기 위해 전기화학적 활성 뿐 만 아니라 높은 전기화학적 내구성이 요구된다. 특히, 연료전지 운 전 중 산소 환원 반응이 일어나는 캐소드에서는 $0.7 \sim$ $1.0 \mathrm{~V}$ 의 높은 전압이 걸리게 되어 있어 금속 나노 입자가 쉽게 용해되거나 서로 뭉치게 되면서 촉매 활성 표면적이 감소되어 연료전지 성능을 저하시키게 된다. 또한 연료전 지 정지/시동 과정 중 애노드에서 수소/산소 경계면이 형 성될 수 있으며 그로 인해 발생하는 역전류 현상에 의해 국부적으로 캐소드에 $1.4 \mathrm{~V}$ 이상의 높은 전압이 걸리게 된다. ${ }^{23)} 1.4 \mathrm{~V}$ 이상의 높은 전압은 촉매 나노 입자의 용 해와 함께 탄소 담지체 부식을 일으켜 연료전지 성능을 급격히 떨어뜨리는 주요 원인이 되고 있다. 따라서 연료 전지의 성능과 내구성을 확보하기 위해서는 연료전지 촉 매를 구성하고 있는 촉매 나노 입자 및 담지체 소재에 대 한 이해가 반드시 필요하며, 이를 통해 적절한 소재를 선 택하고 촉매 반응에 유리한 표면 구조를 개발하는 연구가 매우 중요하다고 할 수 있다.

\subsection{1 백금 $(\mathrm{Pt})$ 계 촉매}

$60 \sim 80{ }^{\circ} \mathrm{C}$ 에서 운전하는 저온형 연료전지 중 수소 이 온 교환막 연료전지(proton exchange membrane fuel cell, $\mathrm{PEMFC}$ ) 및 음이온 교환막 연료전지(anion 
(a)

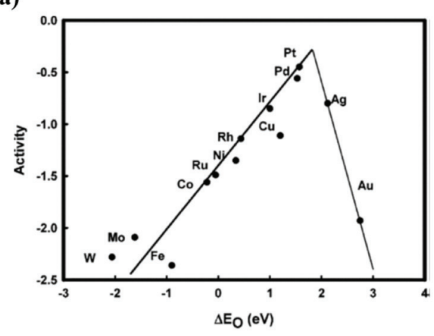

(b)

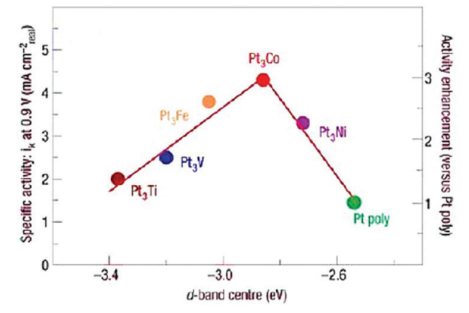

Fig. 9. (a) Trends in ORR activity as a function of $O$ binding energy. ${ }^{24)}$ (b) Correlation between $d$ band center positions and catalytic activities of PtM alloy catalysts. ${ }^{25)}$

exchange membrane fuel cell, AEMFC)에서는 낮은 온도에서도 높은 촉매 활성을 나타내는 $\mathrm{Pt}$ 를 촉매로서 주 로 사용해왔다. 연료전지 반응 중에서도 특히 산소 환원 반응 활성은 산소와의 결합에너지의 크기가 전기화학적 촉매 활성을 결정하는 중요한 인자로서 작용한다고 알려 져 있으며 이러한 산소 결합에너지는 촉매가 가진 $\mathrm{d}$ band 구조(특히, d band center position)에 의해 달라 진다. ${ }^{24,25)}$ 따라서 산소 결합에너지가 너무 강하지도 않고 약하지도 않은 Pt가 단일 원소 촉매로서는 가장 높은 산 소 환원 반응 활성을 보인다고 보고되고 있다. ${ }^{24)}$ 그러나 $\mathrm{Pt}$ 보다 산소 결합에너지를 $0.2 \mathrm{eV}$ 정도 약화시킬 수 있 으면 보다 높은 산소 환원 반응 활성을 나타낼 수 있다는 이론 계산 결과에 따라 $\mathrm{Pt}$ 보다 격자 상수와 전기음성도가 작은 $3 \mathrm{~d}$ 전이 금속을 $\mathrm{Pt}$ 와 합금 $(\mathrm{PtM}$ 합금 촉매, $\mathrm{M}=\mathrm{Co}$, $\mathrm{Ni}, \mathrm{Fe}, \mathrm{Cu}$ 등) 시키는 연구가 활발히 진행되었다. ${ }^{25-27)}$ $\mathrm{PtM}$ 합금 촉매 개발을 통해 촉매 활성점인 Pt의 d band center를 downshift 시켜 산소 결합에너지를 낮춤으로 써 보다 향상된 산소 환원 반응 활성을 확보할 수 있었고, 비싼 Pt의 사용량을 줄일 수 있어 결과적으로 촉매 가격 을 낮추는 긍정적인 효과까지 얻을 수 있었다.

그러나 이와 같은 PtM 합금 촉매는 산소 환원 반응 활 (a)
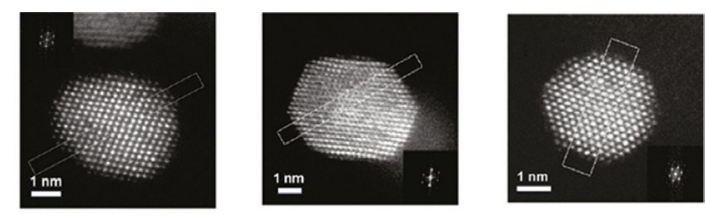

(b)
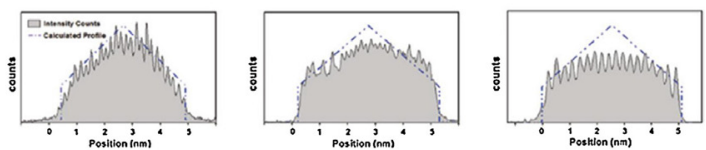

(c)
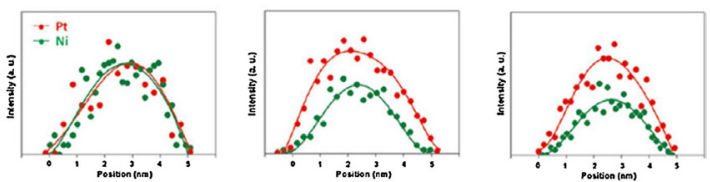

(d)
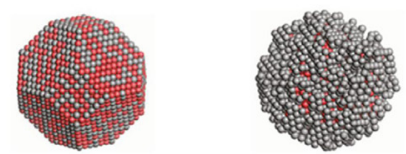

(e)
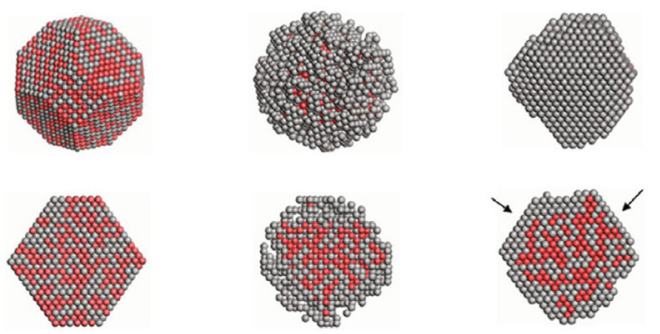

Fig. 10. (a) Representative high-angle annular dark-field scanning transmission electron microscopy (HAADF-STEM) images taken along the zone axis (110), as confirmed by the fast Fourier transfer (FFT) patterns of the STEM images (shown as insets). (b) Background subtracted, normalized intensity line profiles extracted for the regions marked in (a). (c) Composition line profiles (normalized for Pt $L$ peaks) obtained by energy-dispersive $X$-ray spectroscopy (EDX) with an electron beam scanning across individual catalyst particles. (d) Overview and (e) crosssection views of the nanostructures depicted by atomistic particle simulation. The figure is also organized in columns for the as-prepared (left), acid treated (middle), and acid treated/annealed (right) PtNi/C catalysts, respectively. ${ }^{29)}$

성이 매우 높은 장점에도 불구하고 캐소드에 걸리는 높은 구동 전압에 의해 $3 \mathrm{~d}$ 전이 금속이 쉽게 용해되어 합금 효 과가 사라지면서 짧은 시간 안에 촉매 활성이 급격하게 저하되는 현상이 나타나 내구성이 약하다는 단점이 발견 되었다. ${ }^{28)}$ 따라서 이러한 합금 촉매의 내구성을 강화시키 기 위해 합금 되어 있는 $\mathrm{Pt}$ 와 $3 \mathrm{~d}$ 전이 금속 원자 중 $\mathrm{Pt}$ 만 을 의도적으로 표면에 노출시키는 기술이 개발되었다. $\mathrm{PtM}$ 합금 나노 입자를 제조한 뒤 약한 산처리 공정을 통 해 표면에 존재하는 $3 \mathrm{~d}$ 전이 금속을 살짝 녹여 내면 $\mathrm{Pt}$ 원자만 표면에 남아 Pt-skeleton 구조 촉매를 만들 수 
(a)

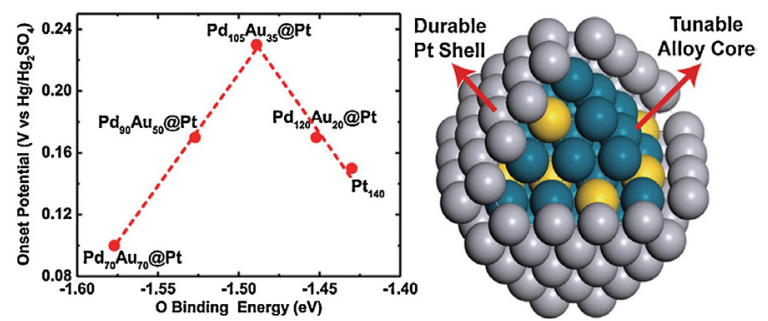

Fig. 11. (a) The onset potential for the ORR at $\mathrm{Pd}_{x} \mathrm{Au}_{1-x} @ P t$ coreshell nanoparticles measured by the rotating disk electrode (RDE) and plotted as a function of the corresponding oxygen binding energy calculated by DFT. (b) Schematic diagram of $\mathrm{Pd}_{x} \mathrm{Au}_{1-x} @ \mathrm{Pt}$ core- shell nanoparticles. ${ }^{31)}$

있다. 이후 약 $200 \sim 300{ }^{\circ} \mathrm{C}$ 정도에서 열처리를 진행하 게 되면 굴곡진 형태의 Pt 표면이 매끄럽게 형성되어 highly coordinated Pt 표면이 만들어 지며 이를 Ptskin 구조 촉매라 부른다. ${ }^{29)}$ 이러한 Pt-skin 구조 촉매 의 표면에는 Pt만 노출되어 있으며 표면 Pt-skin이 내부 에 존재하는 $3 \mathrm{~d}$ 전이 금속 원자를 보호할 수 있어 전체적 인 촉매의 내구성이 향상되는 결과를 가져왔다. ${ }^{29,30)}$

그러나 PtM 합금 촉매의 경우 저렴한 $3 \mathrm{~d}$ 전이 금속을 사용함에도 불구하고 여전히 과량의 Pt가 사용되고 있어 연료전지 촉매의 상용화의 걸림돌이 되었다. 이러한 합금 촉매의 단점을 극복하기 위해 극미량의 $\mathrm{Pt}$ 를 쉘에만 사용 하는 코어-쉘 (core-shell) 구조 촉매가 개발되었으며 촉매 가격을 획기적으로 낮추면서 Pt-skin 구조 촉매와 유사하게 매우 높은 내구성을 가지면서도 높은 촉매 활성 을 보여 줄 것으로 기대되었다. ${ }^{30-32)}$

하지만 이상적으로 낮은 가격의 코어-쉘 구조 촉매를 제작하기 위해서는 코어 물질로 $\mathrm{Co}, \mathrm{Ni}, \mathrm{Fe}$ 과 같은 저렴 한 $3 \mathrm{~d}$ 전이 금속을 사용해야 함에도 불구하고 이러한 $3 \mathrm{~d}$ 전이 금속 나노 입자 표면에 극미량의 $\mathrm{Pt}$ 쉘을 올리는 것 이 매우 어려워 기술적인 한계에 부딪히게 되었다. $\mathrm{Co}$, $\mathrm{Ni}, \mathrm{Fe}$ 등은 근본적으로 산화되기 쉬운 물질이기 때문에 작은 크기의 고분산 된 나노 입자를 만들 수 있다 할 지라 도 공기에 노출되는 순간 표면이 산화되어 얇은 산화물 층이 형성되므로 그 위에 Pt 쉘을 코팅하는 일이 쉽지만 은 않았다. 이러한 기술적 한계로 인해 현실적으로 $\mathrm{Pd}$, $\mathrm{Au}$ 와 같은 귀금속을 코어 물질로 하는 코어-쉘 구조 촉 (a)

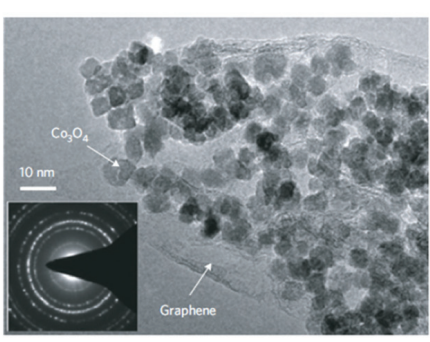

(b)

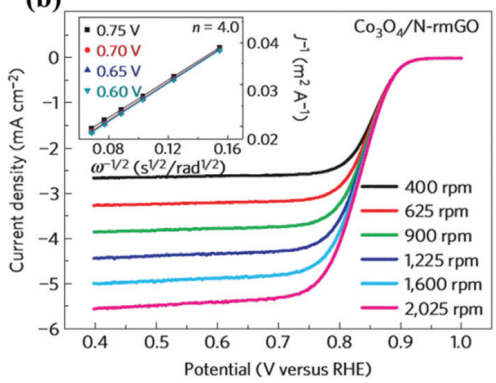

Fig. 12. (a) TEM image and (b) ORR polarization curves (with different rotating speed of rotating disk electrode) of $\mathrm{CO}_{3} \mathrm{O}_{4} / \mathrm{N}-\mathrm{rmGO}$ catalyst. ${ }^{34)}$

매가 우선적으로 개발되었으며 이론적, 실험적 고찰을 통 해 코어-쉘 구조 촉매의 구조적 장점 및 산소 환원 반응 활성 증대 메커니즘 등을 확인하는 연구가 활발히 진행되 었다. ${ }^{31,32)}$ 그러나 귀금속 코어 물질을 사용할 수 밖에 없 다는 현실적인 기술적 한계는 여전히 남아있어 이를 해결 하기 위한 돌파구가 필요하다고 할 수 있다.

\subsection{2비백금계 촉매}

값비싼 Pt 촉매를 대체하기 위한 연료전지 촉매 기술의 개발은 금속 산화물 촉매부터 시작되었다. $\mathrm{MnO}_{2}, \mathrm{Co}_{3} \mathrm{O}_{4}$ 와 같은 금속 산화물 나노 입자는 $\mathrm{pH}$ 가 높은 환경에서 작 동하는 음이온 교환막 연료전지용으로 개발되어 높은 산 소 환원 반응 활성을 보였지만 낮은 전기전도도로 인해 단 독 촉매로서 사용되기에는 다소 문제가 있었다. 따라서 이 를 보완하기 위해 높은 전기전도도를 갖는 탄소 담지체와 의 조합을 시도하였고 질소와 같은 이종 원소가 도핑된 탄 소나노튜브(carbon nanotube, CNT), 그래핀(graphene) 등의 탄소 담지체와 결합시켰을 때 보다 높은 산소 환원 반응 활성이 나타남을 확인할 수 있었다. ${ }^{33,34)}$ 그러나 $\mathrm{pH}$ 
(a)

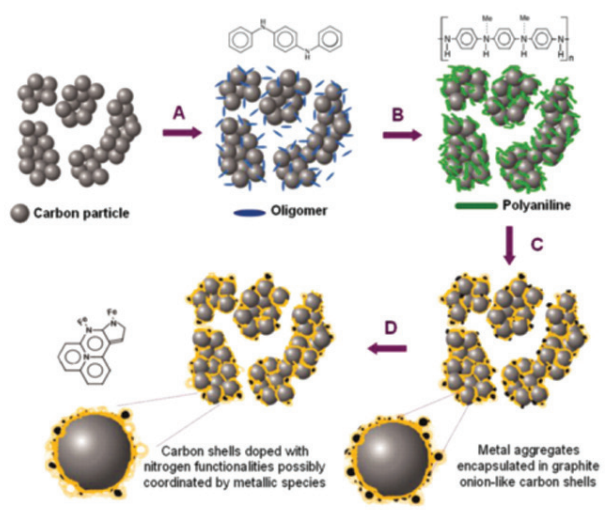

(b)

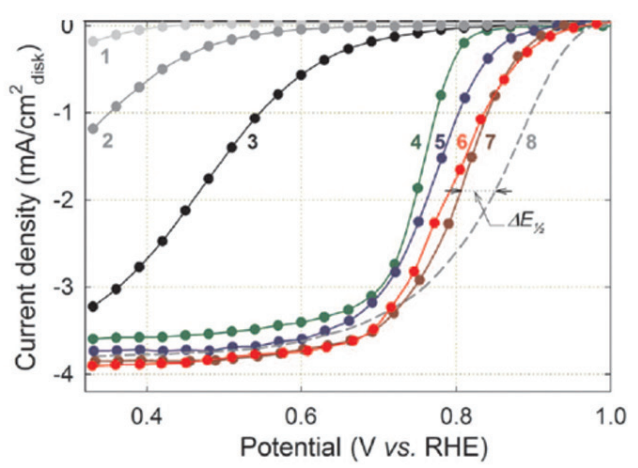

Fig. 13. (a) Schematic diagram of the synthesis of PANI-M-C catalysts. (b) ORR polarization curves of $\mathrm{M}-\mathrm{N}-\mathrm{C}$ catalysts and Pt/C. 1: as received carbon black, 2: heat-treated carbon black, 3: heat-treated PANI-C, 4: PANI-Co-C, 5: PANI-FeCo-C(1), 6: PANI-FeCo-C(2), 7: PANI-Fe-C, 8: $\mathrm{Pt} / \mathrm{C}^{36)}$

가 낮은 환경에서 운전되는 $\mathrm{PEMFC}$ 에서는 상대적으로 매 우 낮은 촉매 활성을 나타내어 촉매 물질로서의 근본적인 한계를 보여주었다고 할 수 있다.

한편, 2000년 대 후반, 금속(metal)-질소(N)-탄소 (C) 결합을 갖는 구조의 촉매 $(\mathrm{M}-\mathrm{N}-\mathrm{C}$ 촉매)가 $\mathrm{pH}$ 가 낮 은 환경에서도 산소 환원 반응 활성이 매우 높게 나타난 다는 것을 발견하고 이를 개발하기 위한 연구가 활발히 진행되었다. ${ }^{35-38)}$ 다양한 물리적/전기화하적 분석을 통해 $\mathrm{M}-\mathrm{N}-\mathrm{C}$ 촉매의 활성점이 질소와 결합하고 있는 금속 원 자라는 것이 밝혀졌고, ${ }^{35)}$ 활성 표면적을 극대화하기 위해 탄소 담지체를 모체로 사용하여 그 표면에 금속-질소탄소 결합을 만들어 내었고 이를 통해 백금 촉매와 유사 한 수준의 고활성 비백금 촉매를 개발할 수 있었다. ${ }^{36)}$ 그 러나 원천적으로 질소와 같은 이종 원소를 과량으로 탄소
소재에 도핑하는 것이 매우 어렵기 때문에 금속 촉매 나 노 입자 수준의 넓은 활성점을 확보하기 어려우며 이로 인해 높은 촉매 성능을 확보하기 위해서는 기존 Pt 촉매 사용량의 3 10배 가량의 $\mathrm{M}-\mathrm{N}-\mathrm{C}$ 촉매를 사용할 수 밖 에 없었다. ${ }^{37)}$ 과량의 촉매를 사용함에 따라 매우 두꺼워 진 전극층 내부에서는 산소와 같은 반응 기체의 확산에 어려움을 주었고 매우 큰 물질 전달 저항 발생으로 인해 낮은 연료전지 성능을 보여주게 되었다. 또한 질소와 결 합한 금속 원자는 전기화학적으로 안정하지 못하여 장시 간 촉매 구동 시 성능 저하가 급격히 발생하는 문제가 나 타나고 있어 아직까지는 실질질적으로 Pt 촉매를 대체하 기에는 부족함이 많다고 할 수 있다. ${ }^{35)}$

\subsection{3 탄소계 촉매}

$\mathrm{Pt}$ 를 대체하면서 더 나아가 금속을 사용하지 않는 촉매 를 개발하는 연구 역시 활발히 진행되고 있다. 금속을 사 용하지 않는 촉매를 개발하게 되면 촉매 가격을 현저히 낮춤과 동시에 연료전지 시스템 자체의 무게를 획기적으 로 줄일 수 있다는 큰 장점을 얻을 수 있다. 예를 들어, 탄 소 소재는 넓은 표면적을 가지면서 높은 전기전도도를 갖 기 때문에 적절한 비금속 촉매 후보가 될 수 있다. 그러나 탄소 소재는 근본적으로 산소 결합에너지가 현저히 낮아 산소의 흡착 자체가 어려우며 그로 인해 산소 환원 반응 활성이 매우 낮다고 알려져 있다. ${ }^{39)}$ 따라서 이러한 탄소 소재의 낮은 촉매 활성을 극대화하기 위해 질소, 황 $(\mathrm{S})$,

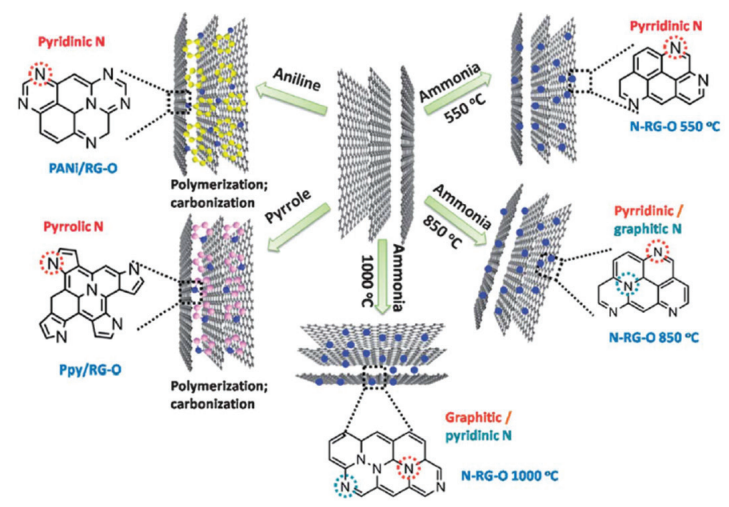

Fig. 14. Schematic diagram of $\mathrm{N}$-doped carbon materials with various $\mathrm{C}-\mathrm{N}$ structures. ${ }^{42)}$ 
특 집 ㅁㅁ윤홍관, 김다희, 김천중, 김용진, 민지호, 정남기

인 $(\mathrm{P})$ 과 같은 이종 원소 도핑을 시도하고 있다. 이 중에 서도 특히, 질소가 도핑 된 탄소나노튜브 또는 그래핀은 높은 산소 환원 반응 활성을 나타내고 있어 이와 관련한 연구가 활발히 이뤄지고 있다. ${ }^{40-42)}$ 탄소 원자보다 최외 각 전자수를 많이 갖고 있는 질소가 탄소 구조에 도핑 되 면 탄소 촉매의 페르미 레벨 (Fermi level)이 상승하여 일 함수 (work function) 값이 감소하게 되고 결과적으로 $n$-type 소재의 성질을 갖게 되며, 감소된 일함수 값에 의해 산소 흡착 후 환원에 필요한 전하 전달이 용이해져 산소 환원 반응 활성이 향상된다고 보고되고 있다. ${ }^{40)}$

그러나 탄소 소재가 가지고 있는 강한 $\mathrm{C}-\mathrm{C}$ 결합을 끊 고 $\mathrm{C}-\mathrm{N}$ 결합을 만들어 내야 하는 이종 원소 도핑 공정은 일반적으로 암모니아 기체 분위기 하에서 $700 \sim 1000$ ${ }^{\circ} \mathrm{C}$ 의 고온 열처리가 수반되어야 하는데, 이때 취약한 열 적 안정성을 갖는 $\mathrm{C}-\mathrm{N}$ 결합이 다시 쉽게 깨지게 되어 열 처리 온도가 높아질수록 도핑 된 질소의 함량이 오히려 감소하게 되는 문제가 발생한다. ${ }^{43)}$ 따라서 탄소 소재의 촉매 활성 면적을 극대화하기 위해서는 탄소 소재의 높은 전도도 및 표면적을 유지하면서 이종 원소 도핑 레벨을 획기적으로 높일 수 있는 기술의 개발이 필요하다고 할 수 있다. 또한 도핑 된 질소가 탄소 원자와 결합하는 구조 는 graphitic N, pyridinic N, pyrrolic N으로 다양하게 나타나고 있으나,42) 정확히 어떤 구조의 결합이 산소 환 원 반응 활성 향상에 직접적으로 도움을 주는지에 대한 의견이 분분하여 아직까지는 초기 연구 단계에 머물고 있 다고 할 수 있다.

\subsection{PEMFC 담지체 소재}

\subsection{1탄소 담지체}

연료전지 촉매의 분산도를 유지하여 넓은 활성 표면적 을 확보하기 위해 금속 나노 입자가 표면적이 넓은 탄소 담지체 위에 올려진 형태의 촉매가 개발되어 왔다. 탄소 소재의 표면에 존재하는 $-\mathrm{CO},-\mathrm{COOH},-\mathrm{CN}$ 과 같은 표면 기능기를 이용하여 금속 나노 입자를 고정시킬 수 있기 때문에 이러한 탄소 담지체를 사용하게 되면 탄소 담지체 위에 고르게 분산된 고활성 촉매를 제조할 수 있

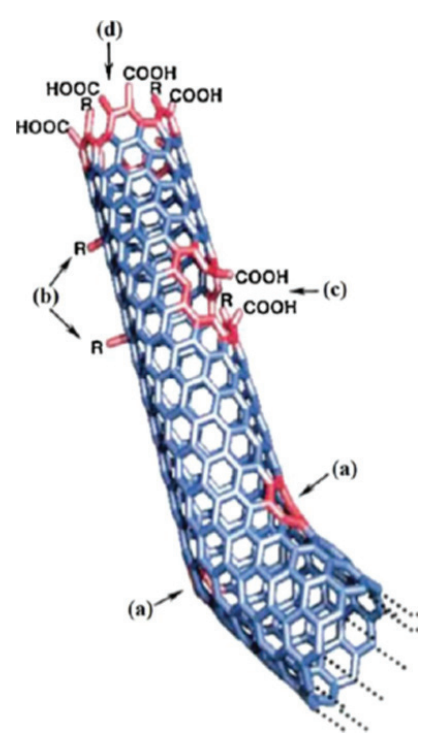

Fig. 15. Typical surface defects on CNT to attach hydrophilic functional groups. (a) Five-or seven-membered rings in the $C$ framework, instead of the normal six-membered ring, leads to a bend in the tube. (b) $\mathrm{sp}^{3}$-hybridized defects $(\mathrm{R}=\mathrm{H}$ and $\mathrm{OH})$. (c) Framework damaged by oxidative conditions, which leaves a hole lined with $\mathrm{COOH}$ groups. (d) Open end of the CNT, terminated with $\mathrm{COOH}$ groups. Besides carboxy termini, the existence of which has been unambiguously demonstrated, other terminal groups such as $\mathrm{NO}_{2}, \mathrm{OH}, \mathrm{H}$, and $\mathrm{O}$ are possible. ${ }^{44)}$

게 된다. ${ }^{44,45)}$ 이러한 탄소 담지체로는 카본블랙(carbon black), 탄소나노튜브, 탄소나노섬유(carbon nanofiber, $\mathrm{CNF})$, 그래핀 등 다양한 구조의 탄소 소재들이 활용 가 능하나, 기본적으로 많은 표면 기능기(또는 표면 결함)를 갖고 있는 카본 블랙을 주로 사용하여 고분산된 연료전지 촉매를 제조해왔다. ${ }^{45-47)}$

한편, 탄소나노튜브나 그래핀과 같은 탄소 소재는 결정 성이 높아 보다 우수한 전기전도도와 화학적 내구성을 갖 고 있는 반면, 표면 결함이 많지 않아 많은 양의 금속 촉 매 나노 입자를 로딩하기 어렵다는 단점을 가지고 있 다. ${ }^{47)}$ 따라서 탄소나노튜브나 그래핀의 표면에 충분히 많 은 기능기를 만들어내기 위해서는 가혹한 산처리 공정이 필요하며 그 결과 이들의 장점인 높은 결정성을 잃게 되 어 결국 화학적 안정성을 포기해야하는 문제가 발생하게 된다. 따라서 이러한 연료전지 촉매 응용을 위한 고결정 성 탄소 소재가 가진 문제점을 해결하기 위해, 정전기적 
(a)

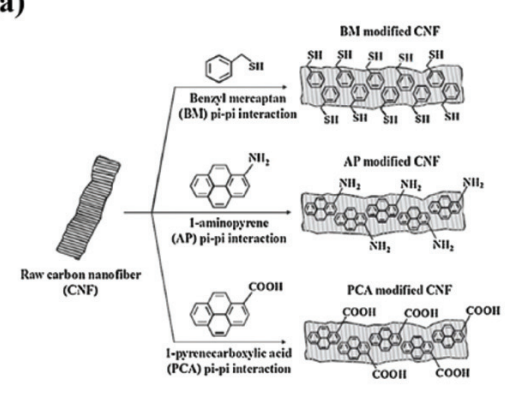

(b)

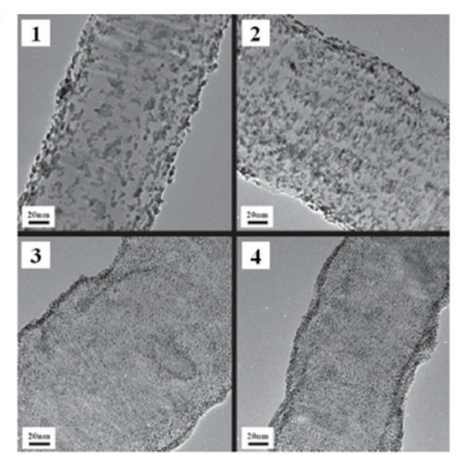

Fig. 16. (a) Schematic diagram of CNF surface functionalization through non-covalent $\pi-\pi$ interaction of various small organic molecules. (b) TEM images of Pt nanoparticles supported on (1) raw CNF, (2) BM-CNF, (3) AP-CNF, and (4) PCA-CNF. ${ }^{47)}$

성질과 $\pi-\pi / \sigma-\pi$ 상호작용을 이용한 non-covalent 표 면 기능화 기술이 개발되기도 하였다. 예를 들면, 음전하 를 띠는 poly (sodium 4-styrenesulfonate)과 같은 소 재로 싸여진 탄소나노튜브를 이용하면 정전기적 인력을 사용하여 양전하를 띠는 금속 전구체를 쉽게 끌어들이게 되고 이를 환원 시키면 탄소나노튜브에 결함을 만들지 않 고 금속 나노 입자를 쉽게 붙일 수 있었다. ${ }^{48)}$ 또한 1-pyrenecarboxylic acid (PCA)와 같은 물질의 pyrene 또는 phenyl 기능기와 탄소나노섬유 표면 탄소 구조 사 이의 $\pi-\pi$ 상호 작용을 활용하여 $\mathrm{PCA}$ 를 탄소 표면에 붙 이게 되면 $\mathrm{PCA}$ 가 가지고 있는 $-\mathrm{COOH}$ 기능기를 anchoring site로 활용하여 금속 나노 입자를 보다 쉽게 붙일 수 있었다. ${ }^{47)}$ 이러한 다양한 탄소 표면 기능화 기술 을 통해, 높은 전기전도도와 화학적 내구성을 갖는 고결 정성 탄소 소재를 연료전지 촉매 담지체로 사용할 수 있 는 가능성을 보여 주고 있다.

\subsection{2금속산화물 담지체}

연료 부족(fuel starvation) 또는 연료전지 정시/시동 시 발생하게 되는 역전류 현상에 의한 캐소드 전압의 상 승 (>1.4 V)은 심각한 탄소 담지체의 부식을 초래하여 연료전지의 성능 저하를 일으키는 주요 원인이 되는 것으 로 밝혀 졌고, 이러한 탄소 담지체 부식에 의한 성능 감소 를 해결하기 위해 보다 높은 전기화학적 내구성을 갖는 신규 담지체의 개발이 필요하였다. ${ }^{23)}$ 금속 산화물은 탄소 소재 보다 화학적으로 안정한 구조를 가지고 있기 때문에 고안정성 담지체로서 좋은 후보 물질 이었으며 많은 연구 자들에 의해 연료전지용 담지체로서의 응용 가능성을 확 인하는 연구가 활발히 진행되었다. 먼저, 금속 산화물 담 지체는 화학적으로 안정한 구조를 가지고 있을 뿐 만 아 니라 금속 나노 입자가 표면에 담지 되었을 때 강한 금 속-담지체 간 상호작용(strong metal-support interaction, SMSI)에 의해 담지된 금속 나노 입자를 안 정적으로 잡고 있을 수 있어 촉매 입자 자체의 내구성 확 보를 위한 긍정적인 효과가 나타남을 확인하였으며, ${ }^{49)}$ 금 속 산화물-촉매 나노 입자 간 전하 이동에 의해 촉매의 활성을 향상시킬 수 있다는 것이 보고되었다. ${ }^{50)}$ 그럼에도 불구하고 금속 산화물 담지체는 근본적으로 탄소 담지체 에 비해 전기전도도가 매우 떨어져 낮은 촉매 성능을 보 였으며 이를 극복하기 위해 $\mathrm{Nb}, \mathrm{Sb}$ 와 같은 원소가 도핑 된 금속 산화물 담지체를 사용하는 기술이 개발되고 있 다. ${ }^{51,52)}$

\section{3. 결론}

본 논문에서는 리튬 이차전지용 전극 소재 및 연료전지 용 촉매의 연구/개발 동향에 대하여 고찰하였다. 리튬 이 차전지용 양극 및 음극 소재로서 다양한 구조를 가지는 무기 소재에 대한 연구 동향을 다루었다. 본론에서 밝힌 바와 같이 리튬 이온의 빠른 확산을 위한 다공성 구조 (open framework) 기반 리튬 이차전지 양극용 무기 소 재의 경우 이미 그 용량의 한계에 다다른 상황이기에 기 존 연구의 패러다임을 극복할 수 있는 새로운 소재에 대 한 연구가 절실한 상황이다. 리튬이차전지용 음극 소재의 
경우, 높은 용량을 나타낼 수 있는 합금계 음극 소재와 탄 소계 음극 소재의 복합화가 많은 연구 그룹에서 진행되고 있다. 또한 차세대 친환경 에너지변환시스템으로서 수소 연료전지에 사용되고 있는 다양한 조성 및 구조를 갖는 촉매 나노 입자와 담지체 소재에 관한 기술 개발 동향에 대한 소개를 하고 이를 바탕으로 연료전지 전극 기술의 발전 방향에 대한 논의를 진행하였다. 특히 촉매 나노 입 자의 경우, 고가의 백금 촉매 개발을 시작으로 하여 백금 의 사용량을 줄이면서 동시에 성능을 향상시킬 수 있는 합금 기술의 개발이 이뤄졌으며, 더 나아가 백금 또는 금 속을 전혀 쓰지 않는 탄소 계열의 촉매까지 연구가 진행 되고 있다. 그러나 연료전지 시스템의 상용화를 위해서는 이러한 연료전지 전극 소재 기술 개발과 함께 수소 생산 및 충전 인프라의 확대가 반드시 필요하며, 이를 통해 실 질적인 수소 경제를 실현하기 위한 플랫폼 구축이 가능할 것이라 사료된다.

끝으로, 우리나라의 에너지 소재 강국으로서 위상을 더 욱 공고히 하기 위하여 높은 성능과 안정성을 동시에 가 지는 리튬 이차전지용 전극 및 연료전지용 촉매 소재에 대한 개발은 매우 시급하다. 깊은 전공 지식과 관련 노하 우를 바탕으로 전문 연구 인력 양성과 다양한 전공 간의 학제 연구를 통하여 새로운 소재의 개발이 이루어질 기대 한다.

\section{참고문헌}

1. Naoki Nitta, F. W., Jung Tae Lee and Gleb Yushin. "Li-Ion Battery Materials: Present and Future" Mater. Today, 18 (5), 252 (2015).

2. Vinodkumar Etacheri, R. M., Ran Elazari, Gregory Salitra and Doron Aurbach. "Challenges in the Development of Advanced Li-Ion Batteries: a Review" Energy Environ. Sci., 4, 3243, (2011).

3. Goodenough, J. B.; Park, K. S. "The Li-Ion Rechargeable Battery: a Perspective" J. Am. Chem. Soc., 135 (4), 1167, (2013).

4. Y. M. Jung, W. W. Cho, "Technology Trend and Future Prospect of Li-Ion Battery (in Korean)" $J$. Am. Ceram. Soc, 13 [5] 7-14 (2010).

5. J. H. Lee, H. Y. Sun, H. S. Kim, S. W. Um, "Development Trend of Rechargeable Battery for
Electric Vehicle (in Korean)" J. Am. Ceram. Soc, 13 [5] 15-28 (2010).

6. H. D. Yoo, E. M., Gregory Salitra, Daniel Sharon and Doron Aurbach. "On the Challenge of Developing Advanced Technologies for Electrochemical Energy Storage and Conversion" Mater. Today, 17 (3), 110 (2014).

7. Ozawa, K. "Lithium-Ion Rechargeable Batteries with $\mathrm{LiCoO}_{2}$ and Carbon Electrodes: the $\mathrm{LiCoO}_{2} / C$ System" Solid State Ion, 69, 212, (1994)

8. RuiWang, X. L., Lei Liu, Jinhyuk Lee, Dong-Hwa Seo, Shou-Hang Bo, Alexander Urban, Gerbrand Ceder. A Disordered Rock-Salt Li-Excess Cathode Material with High Capacity and Substantial Oxygen Redox Activity: $\mathrm{Li}_{1,25} \mathrm{Nb}_{0.25} \mathrm{Mn}_{0,5} \mathrm{O}_{2}$. Electrochem. Commun. 60, 70, (2015)

9. R. Hausbrand, G. C., H. Ehrenberg, M. Gröting, K. Albe, C. Hess, W. Jaegermann. "Fundamental Degradation Mechanisms of Layered Oxide Li-Ion Battery Cathode Materials: Methodology, Insights and Novel Approaches" Mater. Sci. Eng. B, 192, 3 (2015).

10. Yabuuchi, N. Takeuchi, M. Nakayama, M. Shiiba, H. Ogawa, M. Nakayama, K. Ohta, T. Endo, D. Ozaki, T. Inamasu, T.et al. "High-Capacity Electrode Materials for Rechargeable Lithium Batteries: $\mathrm{Li}_{3} \mathrm{NbO}_{4}$-Based System with Cation-Disordered Rocksalt Structure" Proc. Natl. Acad. Sci. US, A, 25, 112, 7650, (2015).

11. S. S. Kim, W. W. Choi, S. M. Lee, "Research and Development Trend of Li-Ion Battery Anode Active Materials(in Korean)" J. Am. Ceram. Soc, 13 [5] 39-44 (2010).

12. Yadong Liu, Q. L., Le Xin, Yuzi Liu, Fan Yang, Eric A. Stach and Jian Xie. "Making Li-Metal Electrodes Rechargeable by Controlling the Dendrite Growth Direction" Nat. Energy, 2, 17083, (2017).

13. Charles de las Casas, W. L. "A Review of Application of Carbon Nanotubes for Lithium Ion Battery Anode Material” J. Power Sources, 208, 74, (2012).

14. Sole, C. Drewett, N. E. Hardwick, L. J. "In Situ Raman Study of Lithium-Ion Intercalation into Microcrystalline Graphite" Faraday Discuss, 172, 223, (2014).

15. Chan, C. K. Peng, H. Liu, G. Mcllwrath, K. Zhang, X. F. Huggins, R. A. Cui, Y. "High-Performance Lithium Battery Anodes using Silicon Nanowires" Nat. Nanotechnol, 3 (1), 31, (2008) 
16. See-How Ng, J. W., David Wexler, Konstantin Konstantinov, Zai-Ping Guo, and Hua-Kun Liu "Highly Reversible Lithium Storage in Spheroidal Carbon-Coated Silicon Nanocomposites as Anodes for Lithium-Ion Batteries" Angew. Chem, 118, 7050, (2006)

17. Dash, R. P., S. "Theoretical Limits of Energy Density in Silicon-Carbon Composite Anode Based Lithium Ion Batteries" Sci. Rep, 6, 27449, (2016).

18. A. S. Prakash, P. M., K. Ramesha, M. Sathiya, J-M. Tarascon and A. K. Shukla. "Solution-Combustion Synthesized Nanocrystalline $\mathrm{Li}_{4} \mathrm{Ti}_{5} \mathrm{O}_{12}$ As High-Rate Performance Li-Ion Battery Anode" Chem. Mater, 22 (2857), (2010).

19. Zhao, L. Hu, Y. S. Li, H. Wang, Z. Chen, L "Porous $\mathrm{Li}_{4} \mathrm{Ti}_{5} \mathrm{O}_{12}$ Coated with $\mathrm{N}-$ Doped Carbon from Ionic Liquids for Li-Ion Batteries" Adv. Mater, 23 (11), 1385, (2011).

20. Jung, H. G. Jang, M. W. Hassoun, J. Sun, Y. K. Scrosati, B. "A high-Rate Long-Life $\mathrm{Li}_{4} \mathrm{Ti}_{5} \mathrm{O}_{12} /$ $\mathrm{Li}\left[\mathrm{Ni}_{0.45} \mathrm{Co}_{0.1} \mathrm{Mn}_{1.45}\right] \mathrm{O}_{4}$ Lithium-Ion Battery" Nat. Commun, 2, 516, (2011).

21. M. Uchida, Y.-C. Park, K. Kakinuma, H. Yano, D. A. Tryk, T. kamino, H, Uchida, and M. Watanabe, "Effect of the State of Distribution of Supported Pt Nanoparticles on Effective Pt Utilization in Polymer Electrolyte Fuel Cells," Phys. Chem. Chem. Phys., 15 11236-11247 (2013).

22. A. Dhanda, H. Pitsch, and R. O'Hayre, "Diffusion Impedance Element Model for the Triple Phase Boundary," J. Electrochem. Soc., 158 [8] B877-884 (2011).

23. C. A. Reiser, L. Bregoli, T. W. Patterson, J. S. Yi, J. D. Yang, M. L. Perry, and T. D. Jarvi, "A ReverseCurrentDecay Mechanismfor FuelCells," Electrochem. Solid-State Lett., 8 [6] A273-A276(2005).

24. J. K. Norskov, J. Rossmeisl, A. Logadottir, L. Lindqvist, J. R. Kitchin, T. Bligaard, and H. Jonsson, "Origin of the Overpotential for Oxygen Reduction at a Fuel-Cell Cathode," J. Phys. Chem. B, 108 [46] 17886-17892 (2004).

25. V. R. Stamenkovic, B. S. Mun, M. Arenz, K. J. J. Mayrhofer, C. A. Lucas, G. Wang, P. N. Ross, and N. M. Markovic, "Trends in Electrocatalysis on Extended and Nanoscale Pt-Bimetallic Alloy Surfaces," Nat. mater., 6 241-247 (2007).

26. S. Guo, D. Li, H. Zhu, S. Zhang, N. M. Markovic, V. R. Stamenkovic, and S. Sun, "FePt and CoPt
Nanowires as Efficient Catalysts for the Oxygen Reduction Reaction," Angew. Chem. Int. Ed., 52 3465-3468 (2013).

27. C. Cui, L. Gan, H.-H. Li, S.-H. Yu, M. Heggen, and P. Strasser, "Octahedral PtNi Nanoparticle Catalysts: Exceptional Oxygen Reduction Activity by Tuning the Alloy Particle Surface Composition," Nano Lett., 12, 5885-5889 (2012).

28. Y.-H. Cho, T.-Y. Jeon, S. J. Yoo, K.-S. Lee, M. Ahn, O.-H. Kim, Y.-H. Cho, J. W. Lim, N. Jung, W.-S. Yoon, H. Choe, and Y.-E. Sung, "Stability Characteristics of $\mathrm{Pt}_{1} \mathrm{Ni}_{1} / \mathrm{C}$ as Cathode Catalysts in Membrane Electrode Assembly of Polymer Electrolyte Membrane Fuel Cell," Electrochim. Acta, 59 264 - 269 (2012).

29. C. Wang, M. chi, D. Li, D. Strmcnik, D. V. Vliet, G. Wang, V. Komanichy, K.-C. Chang, A. P. Paulikas, D. Tripkovic, J. Pearson, K. L. More, N. M. Markovic, and V. R. Stamenkovic, "Design and Synthesis of Bimetallic Electrocatalyst with Multilayered Pt-Skin Surfaces," J. Am. Chem. Soc., 133, 14396-14403 (2011).

30. N. Jung, Y.-H. Chung, D. Y. Chung, K.-H. Choi, H.-Y. Park, J. Ryu, S. -Y. Lee, M. Kim, Y.-E. Sung, and S. J. Yoo, "Chemical Tuning of Electrochemical Properties of Pt-skin Surfaces for Highly Active Oxygen Reduction Reactions," Phys. Chem. Chem. Phys., 15, 17079-17083 (2013).

31. V. R. Stamenkovic, B. Fowler, B. S. Mun, G. Wang, P. N. Ross, C. A. Lucas, and N. M. Markovic, "Improved Oxygen Reduction Activity on $\mathrm{Pt}_{3} \mathrm{~N}_{\mathrm{i}}(111)$ via Increased Surface Site Availability," Science, 315 [5811], 493-497 (2007).

32. M. Oezaslanm M. Heggen, and P. Strasser, "SizeDependent Morphology of Dealloyed Bimetallic Catalysts: Linking the Nano to the Macro Scale," J. Am. Chem. Soc., 134, 514-524 (2011).

33. F. Cheng, Y. Su, J. Liang, Z. Tao, and J. Chen, " $\mathrm{MnO}_{2}$-Based Nanostructures as Catalysts for Electrochemical Oxygen Reduction in Alkaline Media," Chem. Mater., 22, 898-905 (2010).

34. Y. Liang, Y. Li, H. Wang, J. Zhou, J. Wang, T. Regier, and $\mathrm{H}$. Dai, " $\mathrm{Co}_{3} \mathrm{O}_{4}$ nanocrystals on graphene as a synergistic catalyst for oxygen reduction reaction," Nat. Mater., 10, 780-786, (2011).

35. R. Chenm H. Li, D. Chu, and G. Wang, "Unraveling Oxygen Reduction Reaction Mechanisms on CarbonSupportedFe-PhthalocyanineandCo-Phthalocyanine 
Catalysts in Alkaline Solutions," J. Phys. Chem. C, 113, 20689 - 20697 (2009).

36. G. Wu, K. L. More, C. M. Johnston, and P. Zelenay, "High-Performance Electrocatalysts for Oxygen Reduction Derived from Polyaniline, Iron, and Cobalt," Science, 332 [6028], 443-447 (2011).

37. J. Y. Cheon, T.Y. Kim, Y. M. Choi, H. Y. Jeong, M. G. Kim, Y. J. Sa, J. S. Kim, Z. h. Lee, T. H. Yang, K. J. Kwon, O. Terasaki, G. G. Park, R. R. Adzic, and S. H. Joo, "Ordered Mesoporous Porphyrinic Carbons with very High Electrocatalytic Activity for the Oxygen Reduction Reaction," Sci. Rep., 32715 (2013).

38. M. Lefevre, E. Proietti, F. Jaouen, and J. P. Dodelet, "Iron-Based Catalysts with Improved Oxygen Reduction Activity in Polymer Electrolyte Fuel Cells," Science, 324 [5923] 71-74 (2009).

39. M. A. García, and N. V. Rees, "Metal-Free Electrocatalysis : Quaternary-Doped Graphene and the Alkaline Oxygen Reduction Reaction," Appl. Catal. A Gen., 553 107-116 (2018).

40. J. Y. Cheon, J. H. Kim, J. H. Kim, K. C. Goddeti, J. Y. Park, and S. H. Joo, "Intrinsic Relationship between Enhanced Oxygen Reduction Reaction Activity and Nanoscale Work Function of Doped Carbons," J. Am. Chem. Soc., 136 8875-8878 (2014).

41. H. B. Yang, J. Miao, S. F. Hung, J. Chen, H. B. Tao, X. Wang, L. Zhang, R. Chen, J. Gao, H. M. Chen, L. Dai, and B. Liu, "Identification of Catalytic Sites for Oxygen Reduction and Oxygen Evolution in $\mathrm{N}$-doped Graphene Materials: Development of Highly Efficient Metal-Free Bifunctional Electrocatalyst," Sci. Adv., 2 [4] 1-11 (2016).

42. X. Zhou, J. Qiao, L. Yang, and J. Zhang, "A Review of Graphene-Based Nanostructural Materials for Both Catalyst Supports and Metal-Free Catalysts in PEM Fuel Cell Oxygen Reduction Reactions," Adv. Energy Mater., 4 1301523-1301547 (2014).

43. X. Li, H. Wang, J. T. Robinson, H. Sanchez, G. Diankov, and H. Dai, "Simultaneous Nitrogen Doping and Reduction of Graphene Oxide," J. Am. Chem. Soc., 131 15939-15944 (2009).

44. A. Hirsch, "Functionalization of Single-Walled Carbon Nanotubes," Angew. Chem. Int. Ed., 41
1853-1859 (2002).

45. S. C. Roy, A. W. Harding, A. E. Russell, and K. M. Thomas, "Spectroelectrochemical Study of the Role Played by Carbon Functionality in Fuel Cell Electrodes," J. Electrochem. Soc., 144 [7] 2323-2328 (1997).

46. N. Jung, S. M. Kim, D. H. Kang, D. Y. Chung, Y. S. Kang, Y.-H. Chung, Y, W. Choi, C. H. Pang, K.-Y. Suh, and Y.-E. Sung, "High Performance Hybrid Catalyst with Selectively Functionalized Carbon by Temperature-Directed Switchable Polymer," Chem. Mater., 25 1526-1532 (2013).

47. H. -S. Oh, and H. Kim, "Efficient Synthesis of Pt Nanoparticles Supported on Hydrophobic Graphitized Carbon Nanofibers for Electrocatalysts Using Noncovalent Functionalization," Adv. Funct. Mater., 213954 - 3960 (2011).

48. B. W. Yang, X. Wang, F. Yang, C. Yang, and X. Yang, "Carbon Nanotubes Decorated with Pt Nanocubes by a Noncovalent Functionalization Method and Their Role in Oxygen Reduction," $A d v$. Mater., 202579 - 2587 (2008).

49. S. -Y. Huang, P. Ganesan, S. K. Park, and B. N. Popov, "Development of a Titanium DioxideSupported Platinum Catalyst with Ultrahigh Stability for Polymer Electrolyte Membrane Fuel Cell Applications," J. Am. Chem. Soc., 131 13898-13899 (2009)

50. V. T. Ho, C.-J. Pan, J. Rick, W.-N. Su, and B.-J. Hwang, "Nanostructured $\mathrm{Ti}_{0.7} \mathrm{Mo}_{0.3} \mathrm{O}_{2}$ Support Enhances Electron Transfer to Pt: High-Performance Catalyst for Oxygen Reduction Reaction," J. Am. Chem. Soc., 133, 11716 - 11724 (2011).

51. L. Chevallier, A. Bauer, S. Cavaliere, R. Hui, J. Roziere, and D. J. Jones, "Mesoporous Nanostructured $\mathrm{Nb}$-Doped Titanium Dioxide Microsphere Catalyst Supports for PEM Fuel Cell Electrodes," ACS Appl. Mater. Interfaces, 4 1752-1759 (2012).

52. P. K. Mohanta, C. Gokler, A. O. Arenas, and L. Jorissen, "Sb doped $\mathrm{SnO}_{2}$ as a Stable Cathode Catalyst support for Low Temperature Polymer Electrolyte Membrane Fuel Cell," Int. J. Hydrogen Energy, 42 27950-27961 (2017). 


\section{우 윤 홍 관}

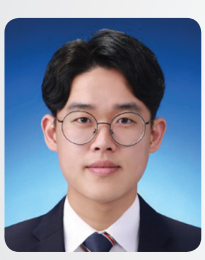

( 2017년-현재 충남대학교 신소재공학과 석사과정

\section{๑๑ 김 용 진}

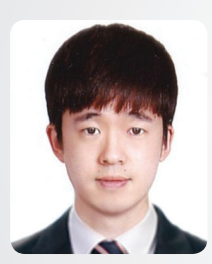

\section{() 2018년-현재 충남대학교}

에너지과학기술대학원 석사과정

\section{이김 천 중}

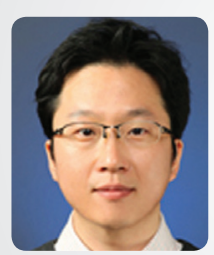

- 2008년 서울대학교 재료공학부 박사

○ 2009년 삼성정밀화학 중앙연구소 책임연구원

ㅇ 2011년 Lawrence Berkeley National Laboratory 박사후연구원

○ 2013년 Univ. of Illinois at Chicago 연구교수

○ 2015년-현재 충남대학교 신소재공학과 조교수

\section{๑๑ 김다 희}

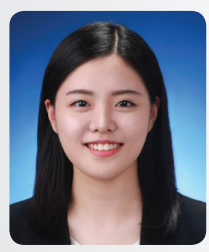

○ 2015-현재 충남대학교 신소재공학과 학사과정

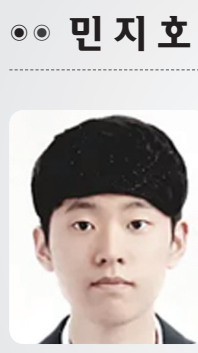

( 2018년-현재 충남대학교

에너지과학기술대학원 석사과정

๑॰ 정 남기

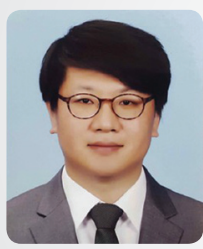

( 2012년 서울대학교 화학생물공학부 박사

○ 2015년 한국과학기술연구원 박사후연구원

○ 2015년-현재 충남대학교

에너지과학기술대학원 조교수 